\title{
Evolution of aerosol chemistry in Xi'an, inland China, during the dust storm period of 2013 - Part 1: Sources, chemical forms and formation mechanisms of nitrate and sulfate
}

\author{
G. H. Wang ${ }^{1,2}$, C. L. Cheng ${ }^{1,3}$, Y. Huang ${ }^{1,3}$, J. Tao ${ }^{4}$, Y. Q. Ren ${ }^{1,3}$, F. Wu ${ }^{1}$, J. J. Meng ${ }^{1,3}$, J. J. Li ${ }^{1}$, Y. T. Cheng ${ }^{1,3}$, \\ J. J. Cao ${ }^{1}$, S. X. Liu ${ }^{1}$, T. Zhang ${ }^{1}$, R. Zhang ${ }^{1}$, and Y. B. Chen ${ }^{1}$ \\ ${ }^{1}$ State Key Laboratory of Loess and Quaternary Geology, Institute of Earth Environment, Chinese Academy of Sciences, \\ Xi' an 710075, China \\ ${ }^{2}$ School of Human Settlements and Civil Engineering, Xi' an Jiaotong University, Xi' an 710079, China \\ ${ }^{3}$ University of Chinese Academy of Sciences, Beijing 100049, China \\ ${ }^{4}$ South China Institute of Environmental Science, Guangzhou 510655, China
}

Correspondence to: G. H. Wang (wanggh@ieecas.cn)

Received: 9 May 2014 - Published in Atmos. Chem. Phys. Discuss.: 30 June 2014

Revised: 13 September 2014 - Accepted: 17 September 2014 - Published: 5 November 2014

\begin{abstract}
A total suspended particulate (TSP) sample was collected hourly in Xi'an, an inland megacity of China near the Loess Plateau, during a dust storm event of 2013 (9 March 18:00-12 March 10:00 LT), along with a sizeresolved aerosol sampling and an online measurement of $\mathrm{PM}_{2.5}$. The TSP and size-resolved samples were determined for elemental carbon (EC), organic carbon (OC), watersoluble organic carbon (WSOC) and nitrogen (WSON), inorganic ions and elements to investigate chemistry evolution of dust particles. Hourly concentrations of $\mathrm{Cl}^{-}, \mathrm{NO}_{3}^{-}$, $\mathrm{SO}_{4}^{2-}, \mathrm{Na}^{+}$and $\mathrm{Ca}^{2+}$ in the TSP samples reached up to 34 , $12,180,72$ and $28 \mu \mathrm{g} \mathrm{m}^{-3}$, respectively, when dust peak arrived over Xi' an. Chemical compositions of the TSP samples showed that during the whole observation period $\mathrm{NH}_{4}^{+}$and $\mathrm{NO}_{3}^{-}$were linearly correlated with each other $\left(r^{2}=0.76\right)$ with a molar ratio of $1: 1$, while $\mathrm{SO}_{4}^{2-}$ and $\mathrm{Cl}^{-}$were well correlated with $\mathrm{Na}^{+}, \mathrm{Ca}^{2+}, \mathrm{Mg}^{2+}$ and $\mathrm{K}^{+}\left(r^{2}>0.85\right)$. Size distributions of $\mathrm{NH}_{4}^{+}$and $\mathrm{NO}_{3}^{-}$presented a same pattern, which dominated in the coarse mode $(>2.1 \mu \mathrm{m})$ during the event and predominated in the fine mode $(<2.1 \mu \mathrm{m})$ during the non-event. $\mathrm{SO}_{4}^{2-}$ and $\mathrm{Cl}^{-}$also dominated in the coarse mode during the event hours, but both exhibited two equivalent peaks in both the fine and the coarse modes during the non-event, due to the fine-mode accumulations of secondarily produced $\mathrm{SO}_{4}^{2-}$ and biomass-burning-emitted $\mathrm{Cl}^{-}$ and the coarse-mode enrichments of urban soil-derived $\mathrm{SO}_{4}^{2-}$
\end{abstract}

and $\mathrm{Cl}^{-}$. Linear fit regression analysis further indicated that $\mathrm{SO}_{4}^{2-}$ and $\mathrm{Cl}^{-}$in the dust samples possibly exist as $\mathrm{Na}_{2} \mathrm{SO}_{4}$, $\mathrm{CaSO}_{4}$ and $\mathrm{NaCl}$, which directly originated from Gobi desert surface soil, while $\mathrm{NH}_{4}^{+}$and $\mathrm{NO}_{3}^{-}$in the dust samples exist as $\mathrm{NH}_{4} \mathrm{NO}_{3}$. We propose a mechanism to explain these observations in which aqueous phase of dust particle surface is formed via uptake of water vapor by hygroscopic salts such as $\mathrm{Na}_{2} \mathrm{SO}_{4}$ and $\mathrm{NaCl}$, followed by heterogeneous formation of nitrate on the liquid phase and subsequent absorption of ammonia. Our data indicate that $54 \pm 20 \%$ and $60 \pm 23 \%$ of $\mathrm{NH}_{4}^{+}$and $\mathrm{NO}_{3}^{-}$during the dust period were secondarily produced via this pathway, with the remaining derived from the Gobi desert and Loess Plateau, while $\mathrm{SO}_{4}^{2-}$ in the event almost entirely originated from the desert regions. Such cases are different from those in the East Asian continental outflow region, where during Asia dust storm events $\mathrm{SO}_{4}^{2-}$ is secondarily produced and concentrates in sub-micrometer particles as $\left(\mathrm{NH}_{4}\right)_{2} \mathrm{SO}_{4}$ and/or $\mathrm{NH}_{4} \mathrm{HSO}_{4}$. To the best of our knowledge, the current work for the first time revealed an infant state of the East Asian dust ageing process in the regions near the source, which is helpful for researchers to understand the panorama of East Asian dust ageing process from the desert area to the downwind region. 


\section{Introduction}

Mineral dust is the largest contributor to particulate matter in the atmosphere, with estimated annual emission fluxes of 1000-3000 Tg (average, $1840 \mathrm{Tg}$ ) at present day (Dentener et al., 1996, 2006; Ginoux et al., 2001). Dust particles can influence the solar radiation directly by scattering sunlight and indirectly by acting as cloud condensation nuclei (CCN) and ice nuclei (IN) (Buseck and Pósfai, 1999; Formenti et al., 2011; Manktelow et al., 2010). The Gobi desert of northern China and Mongolia and the Taklamakan desert of western China are the major source regions of East Asian dust (McNaughton et al., 2009; Mochida et al., 2007). Modeling results indicate that around $100-460 \mathrm{Tg} \mathrm{yr}^{-1}$ of dust is emitted annually from the East Asia source regions (Laurent et al., 2006) and transported eastwardly, exerting a significant impact on the atmosphere over the downwind regions, including eastern coastal China (Arimoto et al., 2006; Kim et al., 2004; Li et al., 2014; $\mathrm{Li}$ and Shao, 2009; Sun et al., 2010; Wang et al., 2013; Wang et al., 2012), Korea (Geng et al., 2014; Song et al., 2013; Sullivian et al., 2007), Japan (Takahashi et al., 2011; Tobo et al., 2010; Uno et al., 2009) and western North America (Huebert et al., 2003; Leaitch et al., 2009; McNaughton et al., 2009; Parrington et al., 1983; Singh et al., 2009). A recent study found that dust from the Sahara and Asia is transported over the Pacific Ocean and increases the snow precipitation in mountainous areas of Nevada, USA (Creamean et al., 2013). In addition to the impact on climate, dust storm also affect marine productivity because dust-bonded iron, nitrogen and phosphorus are the most important nutrients to marine microbes (Boyd et al., 2007; Duce et al., 2008; Jickells et al., 2005; Kanakidou et al., 2012; Zamora et al., 2011, 2013).

Due to rapid urbanization and industrialization in China, annual consumption of coal has increased to 3.61 billion tons in the country recently (China Statistic Press, 2010), along with a sharp increase in vehicle numbers, resulting in high burdens of $\mathrm{SO}_{2}, \mathrm{NO}_{\mathrm{x}}$, elemental carbon (EC), organic matter, nitrate, sulfate and other pollutants in the atmosphere over China (Geng et al., 2014; He, 2014; Huang et al., 2014; van Donkelaar et al., 2010; Wang et al., 2014). During longrange transport, dust can become coated with nitrate, sulfate, ammonium and other pollutants, leading to a series of changes in dust behavior in the atmosphere such as water uptake, deposition and scattering sunlight (Boreddy et al., 2014; Creamean et al., 2013; Formenti et al., 2011; Grassian, 2001; Seinfeld et al., 2004; Sullivan et al., 2009). Studies found that $\mathrm{SO}_{2}$ level in the atmosphere of China has become stable and even decreased since 2006 because the Chinese government has promulgated a strict standard on $\mathrm{SO}_{2}$ emission $(\mathrm{Lu}$ et al., 2010; Menon et al., 2008; Wang et al., 2013). As a result, atmospheric sulfate aerosol loading has been decreasing in many Chinese urban regions since 2006, whereas $\mathrm{NO}_{\mathrm{x}}$ and particulate nitrate levels have kept stable and even increased (Wang et al., 2011, 2012, 2013; Zhang et al., 2009).
Due to the chemical affinity of nitrogen oxides and nitric acid with dust particles (Hanisch and Crowley, 2001; Mogili et al., 2006; Saliba and Chamseddine, 2012; Song et al., 2013; Usher et al., 2003), such a change in the atmospheric environment of China suggests that dust particle behavior might also be changing compared to the situations 10 years ago. Therefore, it is necessary to investigate the present physicochemical properties of airborne particles in the country during dusty periods.

In the past decades, numerous observations have been conducted along the Asian dust transport pathways - including eastern coastal China, Korea, Japan, the Pacific Ocean and western North America - to investigate the ageing process of East Asian dust during long-range transport (Huebert et al., 2003; Kim et al., 2004). In contrast, only a few field measurements have been done in the upstream regions, especially inland cities of China (Arimoto et al., 2004; Huang et al., 2010), where the dust particle ageing could be in the infant state due to the proximity of the source regions, including deserts and the Loess Plateau. Xi' an is a megacity in inland China, which is located at the south edge of Loess Plateau. A high level of particle pollution has been a persistent problem in the city (Shen et al., 2008). In comparison with that $\left(55 \mu \mathrm{g} \mathrm{m}^{-3}\right.$, unpublished data) in 1997, the annual level $\left(27 \mu \mathrm{g} \mathrm{m}^{-3}\right.$, unpublished data) of sulfate of $\mathrm{PM}_{2.5}$ of the city in 2012 has decreased by a factor of around 2 due to the $\mathrm{SO}_{2}$ emission control, while $\mathrm{NO}_{\mathrm{x}}$ and nitrate have increased about $25 \%$. Acidic gas concentration is a key factor affecting heterogeneous reaction rates of dust particles with $\mathrm{SO}_{2}, \mathrm{NO}_{\mathrm{x}}$ and $\mathrm{HNO}_{3}(\mathrm{~g})$, apart from relative humidity, temperature and dust mineralogy and morphology. For example, calcite $\left(\mathrm{CaCO}_{3}\right)$, which is a common component of East Asian dust and accounts for 3.6-21\% of the dust mass (Liu, 1985), can rapidly convert to $\mathrm{Ca}\left(\mathrm{NO}_{3}\right)_{2}$ in less than 3 min under 1 ppbv $\mathrm{HNO}_{3}(\mathrm{~g})$ but longer than $4 \mathrm{~h}$ under a low- $\mathrm{HNO}_{3}$ (g) mixing ratio (10 pptv) (Sullivan et al., 2009). Since $\mathrm{Ca}\left(\mathrm{NO}_{3}\right)_{2}$ is highly hygroscopic, the chemically modified dust can absorb water vapor and form a liquid phase on the surface (Li et al., 2014). Therefore, changes in physicochemical properties of dust particles occur and are probably much more significant than before due to the recent increase in $\mathrm{NO}_{\mathrm{x}}$ emission. In order to investigate the impact of dust storms on the downwind aerosol chemistry under the current high level of $\mathrm{NO}_{\mathrm{x}}$ and relatively low level of $\mathrm{SO}_{2}$ conditions, we performed an intensive filter-based sampling with a $1 \mathrm{~h}$ time resolution to investigate chemical evolution of urban airborne particles in Xi' an in the period of 9-12 March 2013, during which the annual heaviest dust storm passed through the city with an hourly maximum of total suspended particulate (TSP) of more than $7000 \mu \mathrm{g} \mathrm{m}^{-3}$. In the present work, we focus on the changes in aerosol chemistry specifically nitrate and sulfate during the event. We first investigated the composition and size distribution of airborne particles in the event and compared with those in the non-event to discuss the chemical evolution of dust particles. Then we identified the 
chemical forms of nitrates and sulfates existing in the dust to explore their sources and formation mechanisms. We found for the first time an enrichment of ammonium nitrate in the dust particles, which is different from a fine-mode accumulation of ammonium sulfate in Asia continental outflow regions such as the western North Pacific and western North America. Our results further revealed that such a phenomenon is relevant to the water-soluble components of mineral dusts, which consist of hygroscopic salts (e.g., $\mathrm{NaCl}$ and $\mathrm{Na}_{2} \mathrm{SO}_{4}$ ) and originate from dried salt lakes in western China and the Gobi desert.

\section{Experimental section}

\subsection{Collections of TSP and size-resolved samples}

TSP samples were collected hourly at an airflow rate of $1.0 \mathrm{~m}^{3} \mathrm{~min}^{-1}$ from 9 March at 18:00 to 12 March at 10:00 LT by using two TCH-1000 air samplers (Tianhong Company, China) on the rooftop of a three-story building on the campus of the Institute of Earth Environment, CAS, which is located in the downtown area of Xi'an. Simultaneously, sizesegregated samples were also collected, with each set lasting for $3 \mathrm{~h}$ during the dust storm period and $12 \mathrm{~h}$ during the nondust period, by using two size-resolved samplers (Series 20800, Thermo Electron Corporation USA). The cutoff points of the size-segregated samples are $0.43,0.65,1.1,2.1,3.3$, 4.7, 5.8 and $9.0 \mu \mathrm{m}$ at an airflow rate of $28.3 \mathrm{~L} \mathrm{~min}^{-1}$. All the samples were collected onto pre-combusted quartz filters $\left(450^{\circ} \mathrm{C}\right.$ for $\left.6 \mathrm{~h}\right)$. Field blank samplers were also collected at the beginning and the end of the sampling campaign by mounting pre-baked blank filters onto the samplers for about 10 min without sucking any air. After sampling, all the filters were individually sealed in aluminum foil bags and stored at $-20^{\circ} \mathrm{C}$ prior to analysis. A total of $65 \mathrm{TSP}$ samples and six sets of size-segregated samples were collected. In addition to the above filter-based sampling, online measurement of $\mathrm{PM}_{2.5}$ was also conducted by using a E-BAM-9800 analyzer (Met One, USA).

\subsection{Analyses of TSP and size-resolved samples}

\subsubsection{Inorganic ions, water-soluble organic (WSOC) and inorganic carbon (WSIC), and water-soluble organic nitrogen (WSON)}

Aliquot (size: $12.56 \mathrm{~cm}^{2}$ ) of the filter was cut into pieces and extracted three times with Milli-Q pure water under sonication. One part of the combined water extracts was determined for inorganic ions using Dionex-6000 ion chromatography. Another part of the water extracts was determined for watersoluble organic carbon (WSOC), water-soluble inorganic carbon (WSIC) and water-soluble total nitrogen (WSTN) using a Shimadzu 5000 TOC/N Analyzer. The detailed analysis methods for inorganic ions, WSOC and WSTN can be found elsewhere (Wang et al., 2010). $\mathrm{NO}_{3}^{-}$and $\mathrm{NH}_{4}^{+}$are the major water-soluble inorganic nitrogen (WSIN) species in airborne particles; thus the difference between WSTN and WSIN is defined as water-soluble organic nitrogen (WSON).

\subsubsection{Organic carbon (OC) and elemental carbon (EC)}

OC and EC in the TSP samples were measured by a DRI Model 2001 Carbon Analyzer using the Interagency Monitoring of Protected Visual Environments (IMPROVE) thermal/optical reflectance (TOR) protocol. Briefly, a $0.53 \mathrm{~cm}^{2}$ filter was put in a quartz boat inside the analyzer and progressively heated to temperatures of $120,250,450$ and $550{ }^{\circ} \mathrm{C}$ in a non-oxidizing helium (He) atmosphere, and 550, 700 and $800{ }^{\circ} \mathrm{C}$ in an oxidizing atmosphere containing $2 \%$ oxygen in helium.

\subsubsection{Elements}

Elements of the TSP samples were determined by energydispersive X-ray fluorescence (ED-XRF) spectrometry (Epsilon 5 ED-XRF, PANalytical B. V., Netherlands). The X-ray source is a side window $\mathrm{X}$-ray tube with a gadolinium anode and operated at an accelerating voltage of $25 \mathrm{e} 100 \mathrm{kV}$ and a current of $0.5 \mathrm{e} 24 \mathrm{~mA}$ (maximum power: $600 \mathrm{~W}$ ). The characteristic X-ray radiation is detected by a germanium detector (PAN 32). Each sample was analyzed for $30 \mathrm{~min}$ to obtain a spectrum of X-ray counts versus photon energy, with the individual peak energies matching specific elements and peak areas corresponding to elemental concentrations. The spectrometer was calibrated with thin-film standards obtained from MicroMatter Co. (Arlington, WA, USA). In the current study, 14 elements (i.e., S, Cl, K, Ca, Ti, Mn, Fe, Zn, Cr, $\mathrm{Ni}, \mathrm{As}, \mathrm{Br}, \mathrm{Mo}, \mathrm{Pb}$ ) were determined. The element concentrations for blank quartz fiber filter are $0.00-0.66 \mu \mathrm{g} \mathrm{cm}^{-2}$, lower than $10 \%$ of those in the TSP samples.

\section{Results and discussion}

During the sampling period a massive dust storm event originating from the Mongolian Gobi desert arrived over Xi' an on 9 March with a highest TSP level of $7527 \mu \mathrm{g} \mathrm{m}^{-3}$ in the beginning hour (18:00LT) and a second peak on 10 March at 13:00. From 9 March at 18:00 to 10 March at 21:00 LT, the TSP level decreased from the highest to less than $1000 \mu \mathrm{g} \mathrm{m}^{-3}$, which is a typical level of TSP in Xi' an during spring. A $48 \mathrm{~h}$ backward-trajectory analysis indicated a three-phase pattern for the movements of air masses arrived in Xi' an during the sampling period. As seen in Fig. 1, the $48 \mathrm{~h}$ backward trajectories showed that from 9 March at 18:00 to 10 March at 21:00 air parcels originated from the Gobi desert of Mongolia and northern China and directly moved to Xi' an at 100, 300 and $500 \mathrm{~m}$ levels above the ground along the same tracks. TSP within this period ranged from 774 to $7527 \mu \mathrm{g} \mathrm{m}^{-3}$ with an average of 
(a) Dust storm period (Phase I)

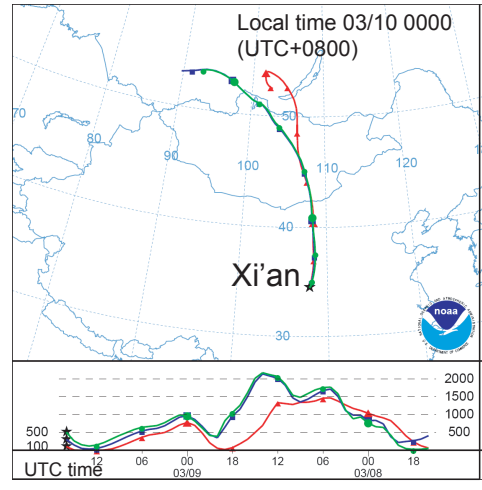

(c) Transition period (Phase II)

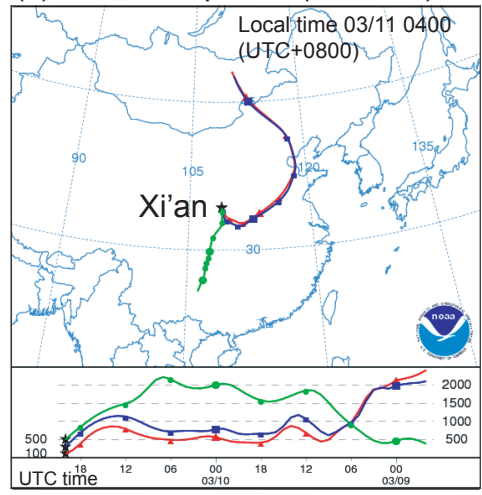

(b) Dust storm period (Phase I)

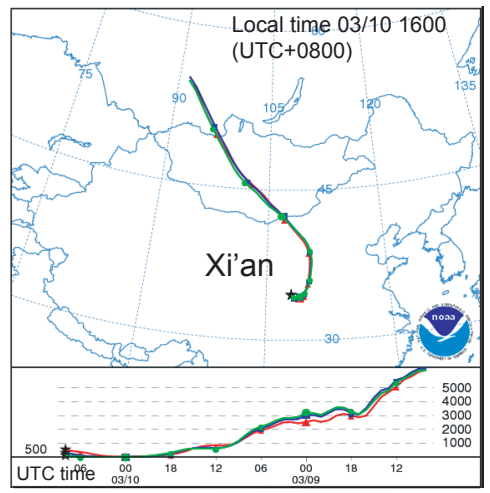

(d) Non-dust storm period (Phase III)

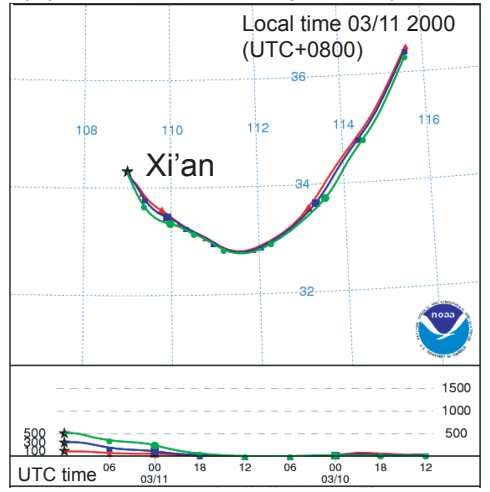

(e) Topography of Guanzhong Basin and its surrounding areas

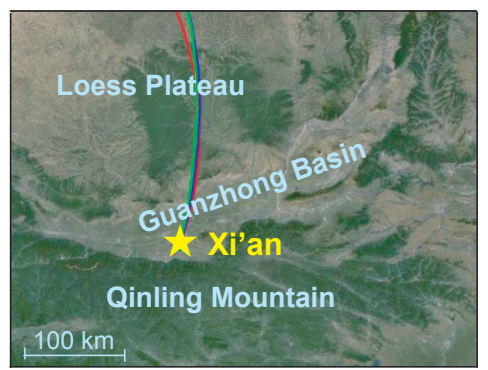

Phase I: Dust storm period (9 March at 18:00-10 March at 21:00)

Phase II: Transition period (10 March at 21:00-11 March at 12:00)

Phase III: Non-dust storm period (11 March at 12:00- 12 March 10:00)

Figure 1. Backward trajectories of air masses arriving in Xi'an during the campaign (a-d) and the topography of the Guanzhong Basin and its surrounding areas (e) (duration $48 \mathrm{~h}$; air parcels of 100, 300 and $500 \mathrm{~m}$ above ground level are in red, blue and green, respectively).

$2109 \pm 1360 \mu \mathrm{g} \mathrm{m}^{-3}$. We classified this period as the dust storm event (Phase I; see Fig. 1a and b for examples). From 10 March at 21:00 to 11 March at 12:00 LT, air parcels at the 100 and $300 \mathrm{~m}$ levels still originated from the Gobi desert but moved to eastern coastal China first and then returned to Xi'an, while the $500 \mathrm{~m}$ air parcel originated from southern China and moved slowly to Xi' an after spanning over the Qinling Mountains (Fig. 1c and e). During this period the TSP level ranged from 412 to $1037 \mu \mathrm{g} \mathrm{m}^{-3}$ with an average of $630 \pm 155 \mu \mathrm{g} \mathrm{m}^{-3}$ (Table 1, hereinafter). We classified this period as the transition period (Phase II; see Fig. 1c for example). After 11 March at 12:00, the three levels of air parcels originated from the North China Plain and moved to Xi' an from the Qinling Mountains (about $1500 \mathrm{~m}$ above the ground level, Fig. 1d and e). During this period the TSP varied from 476 to $1399 \mu \mathrm{g} \mathrm{m}^{-3}$ with an average of $687 \pm 194 \mu \mathrm{g} \mathrm{m}^{-3}$. We classified this period as the non-dust-storm period (Phase III; see Fig. 1d for example). As seen in Fig. 1e, Xi' an is 


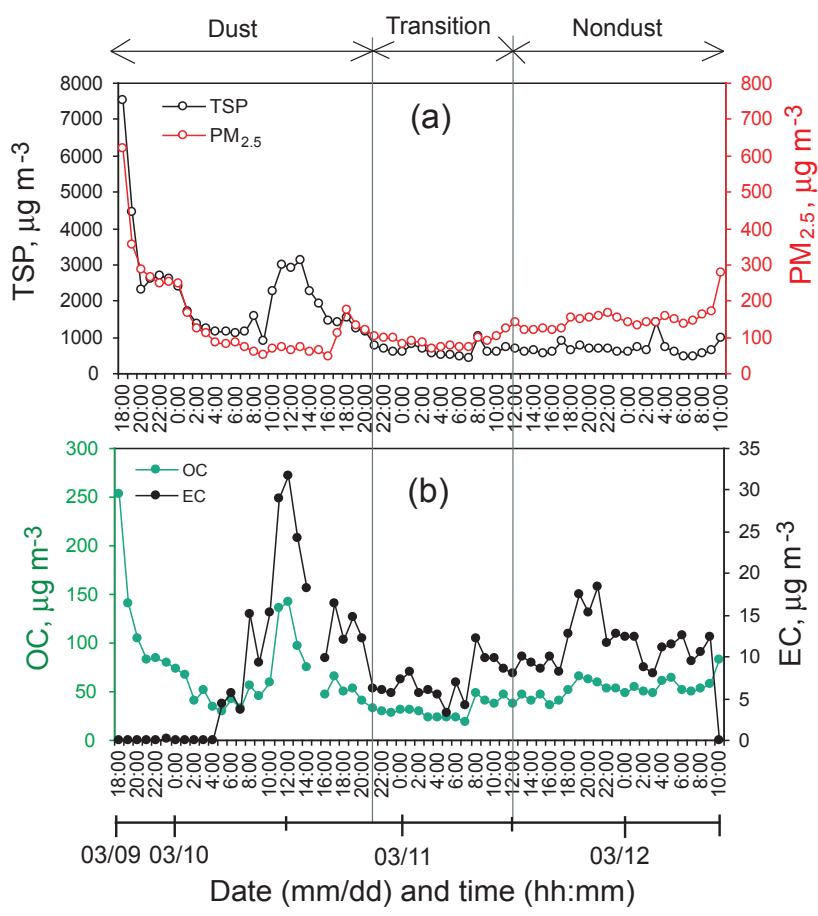

Figure 2. Temporal variations of TSP, $\mathrm{PM}_{2.5}$, EC and OC during the campaign.

located in the Guanzhong Basin and very close to the Qinling Mountains. From the transport tracks it can be seen that air parcels within Phase III moved much slower in comparison with those in Phase I and Phase II. Thus, we believe that aerosols in the non-dust-storm period are mostly derived from the local sources rather than from long-range transport. In the following sections we will discuss the aerosol chemistry evolution based on the three classified categories.

\subsection{Hourly changes in chemical compositions of ambient particles}

As shown in Fig. 2a, during the dust storm period TSP showed two maxima, with the largest peak at the first hour (i.e., 9 March at 18:00 LT) and a second peak at noontime (11:00-13:00 LT) on 10 March. At the same time $\mathrm{PM}_{2.5}$ concentration was $152 \pm 127 \mu \mathrm{g} \mathrm{m}^{-3}$ with a maximum of $621 \mu \mathrm{g} \mathrm{m}^{-3}$ occurring in the first hour (Fig. 2a). As shown in Table 1, relative abundances of $\mathrm{PM}_{2.5}$ / TSP were $7.4 \pm 3.4 \%, 14 \pm 2.3 \%$ and $23 \pm 4.8 \%$ during the dust storm event, transition period and non-dust-storm event, respectively, suggesting that surface soils in the Gobi desert and Loess Plateau consist of a certain amount of fine particles. From the backward trajectories we found that air parcels in the first $10 \mathrm{~h}$ directly moved across the Guanzhong Basin from the north to the south (as exemplified in Fig. 1a), sweeping pollutants out of Xi' an. Then the air mass moved to Xi'an from the east on 10 March at 10:00 LT (see Fig. 1b for an example), with pollutants originating from the upwind cities

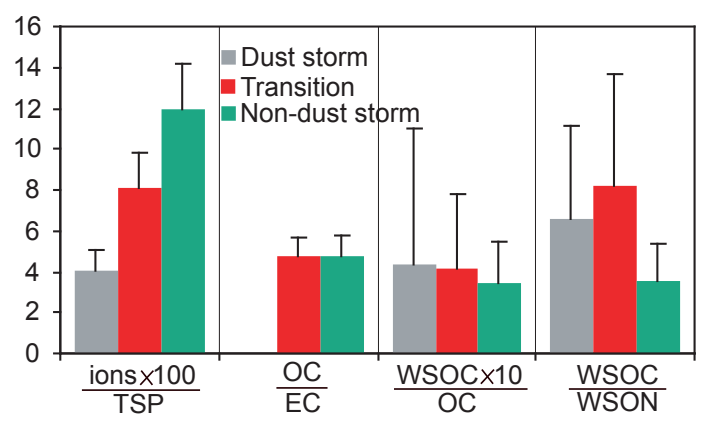

Figure 3. Comparison of relative abundance of ions, OC, EC, WSOC and WSON in the TSP samples during the dust storm event, transition time and non-dust-storm period.

such as Weinan and Huayin. As a result, EC was almost undetectable in the beginning $10 \mathrm{~h}$ but sharply increased to more than $30 \mu \mathrm{g} \mathrm{m}^{-3}$ at noontime on 10 March during the dust storm period (Fig. 2b).

Total inorganic ions in the dust storm, transition and nondust-storm periods accounted for $4 \%, 8 \%$ and $12 \%$ of the TSP mass, respectively (Fig. 3). In contrast, concentration ratios of WSOC to OC at the three periods gradually decreased from 0.4 in the dust period to 0.3 in the non-dust period (Fig. 3), which is lower than that $(0.5 \pm 0.1)$ observed for dust storm events in the spring of 2009 (Wang et al., 2013). Our previous studies found that dusts from the Gobi desert contain significant amounts of water-soluble organic compounds, e.g., trehalose (Wang et al., 2011, 2012). In addition, heterogeneous formation of secondary organic aerosols (SOAs) on dust surface is another important contributor to WSOC of dust (Sullivan and Prather, 2007; Wang et al., 2013). Therefore, in comparison with that in spring of 2009 the lower ratio of WSOC/OC is most likely due to the differences in the dust source regions and/or SOA formation on the dust surface. The OC/EC ratio presented similar values during the transition and non-dust periods, with an average value around 4.0, which is higher than that for $\mathrm{PM}_{2.5}$ in the city since coarse particles contain a lower amount of elemental carbon. Our previous investigation on the impact of Asian dust storms on Xi' an aerosols in the spring of 2009 found that $88 \%$ (in mass) of airborne particulate sulfate originated from Gobi desert soil in the presence of the dust storm (Wang et al., 2011, 2013). A recent study on the atmospheric aerosols collected in the Taklamakan desert also reported that airborne particles in the desert are abundant in sulfate, which accounts for about $4 \%$ of the particle mass with no significant difference for particles with different sizes (Wu et al., 2012). WSOC / WSON ratios are higher in the dust storm and transition periods and lower in the non-dust period, which can be ascribed to more WSON species emitted from anthropogenic sources such as agricultural fertilizer and livestock dejecta (Cape et al., 2011; Chen et al., 2010; Wang et al., 2010). 
Table 1. Meteorological parameters and hourly concentrations of inorganic ions, elements, EC, OC, water-soluble organic (WSOC) and inorganic carbon (WSIC), and water-soluble organic (WSON) and inorganic nitrogen (WSIN) in total suspended particles (TSP) during the dust storm, transition and non-dust periods.

\begin{tabular}{|c|c|c|c|}
\hline Time & $\begin{array}{l}\text { Dust storm } \\
\text { (9 March at 18:00- } \\
10 \text { March at 21:00) }\end{array}$ & $\begin{array}{l}\text { Transition } \\
(10 \text { March at 21:00- } \\
11 \text { March at 12:00) }\end{array}$ & $\begin{array}{l}\text { Non-dust storm } \\
\text { (11 March at 12:00- } \\
12 \text { March at 10:00) }\end{array}$ \\
\hline \multicolumn{4}{|c|}{ I. Meteorological parameters and online measured $\mathrm{PM}_{2.5}$} \\
\hline Relative humidity (RH, \%) & $22 \pm 3.5(14-26)$ & $53 \pm 9.0(34-64)$ & $48 \pm 6.0(33-61)$ \\
\hline Wind speed (WS, $\left.\mathrm{ms}^{-1}\right)$ & $2.0 \pm 0.6(0.7-2.9)$ & $1.6 \pm 0.7(0.7-3.5)$ & $2.1 \pm 0.8(0.4-3.2)$ \\
\hline Temperature $\left(T,{ }^{\circ} \mathrm{C}\right)$ & $13 \pm 2.7(9.1-20)$ & $5.4 \pm 1.7(3.3-8.5)$ & $10 \pm 1.3(8.8-15)$ \\
\hline $\mathrm{PM}_{2.5}, \mu \mathrm{g} \mathrm{m}^{-3}$ & $152 \pm 127(49-621)$ & $88 \pm 16(68-125)$ & $150 \pm 32(119-279)$ \\
\hline \multicolumn{4}{|c|}{ II. Inorganic ions in TSP samples, $\mu \mathrm{g} \mathrm{m}^{-3}$} \\
\hline $\mathrm{F}^{-}$ & $0.5 \pm 0.4(0.1-1.3)$ & $0.6 \pm 0.3(0.2-1.3)$ & $0.8 \pm 0.2(0.3-1.0)$ \\
\hline $\mathrm{Cl}^{-}$ & $5.1 \pm 6.3(1.7-34)$ & $2.8 \pm 0.8(1.7-4.9)$ & $4.3 \pm 2.0(1.9-11)$ \\
\hline $\mathrm{NO}_{2}^{-}$ & $0.3 \pm 0.2(0.0-0.7)$ & $0.3 \pm 0.1(0.0-0.4)$ & $0.2 \pm 0.1(0.0-0.3)$ \\
\hline $\mathrm{NO}_{3}^{-}$ & $8.2 \pm 2.1(4.7-12)$ & $11 \pm 2.0(7.6-15)$ & $28 \pm 3.5(20-34)$ \\
\hline $\mathrm{SO}_{4}^{2-}$ & $35 \pm 34(12-180)$ & $14 \pm 3.3(10-20)$ & $21 \pm 4.3(15-33)$ \\
\hline $\mathrm{Na}^{+}$ & $18 \pm 13(5.2-72)$ & $8.7 \pm 1.5(5.4-11)$ & $3.9 \pm 4.1(0.0-13)$ \\
\hline $\mathrm{NH}_{4}^{+}$ & $3.0 \pm 0.7(1.7-5.1)$ & $3.5 \pm 1.0(2.4-5.9)$ & $7.6 \pm 0.9(5.6-8.7)$ \\
\hline $\mathrm{K}^{+}{ }^{4}$ & $1.5 \pm 0.8(0.7-4.1)$ & $0.8 \pm 0.2(0.4-1.2)$ & $1.4 \pm 0.5(0.9-3.0)$ \\
\hline $\mathrm{Mg}^{2+}$ & $1.3 \pm 0.7(0.3-3.8)$ & $0.7 \pm 0.2(0.3-1.1)$ & $0.7 \pm 0.3(0.3-1.4)$ \\
\hline $\mathrm{Ca}^{2+}$ & $10 \pm 5.9(1.7-28)$ & $6.6 \pm 1.9(2.8-9.8)$ & $11 \pm 2.5(6.9-15)$ \\
\hline Subtotal & $83 \pm 60(37-340)$ & $49 \pm 8.4(36-65)$ & $79 \pm 10(56-103)$ \\
\hline \multicolumn{4}{|c|}{ III. Elements in TSP samples, $\mu \mathrm{g} \mathrm{m}^{-3}$} \\
\hline $\mathrm{S}$ & $18 \pm 11(7.9-56)$ & $7.9 \pm 1.9(5.7-12)$ & $13 \pm 2.2(9.3-19)$ \\
\hline $\mathrm{Cl}$ & $6.2 \pm 6.0(2.0-30)$ & $2.5 \pm 1.3(1.5-6.4)$ & $6.6 \pm 2.4(3.9-12)$ \\
\hline $\mathrm{K}$ & $64 \pm 39(28-195)$ & $15 \pm 4.2(9.0-21)$ & $20 \pm 4.6(13-33)$ \\
\hline $\mathrm{Ca}$ & $146 \pm 81(66-411)$ & $45 \pm 15(26-71)$ & $55 \pm 13(35-98)$ \\
\hline $\mathrm{Ti}$ & $9.7 \pm 6.0(4.3-30)$ & $2.4 \pm 0.7(1.4-3.4)$ & $2.5 \pm 0.6(1.8-4.8)$ \\
\hline $\mathrm{Mn}$ & $1.2 \pm 1.0(0.0-4.3)$ & $0.5 \pm 0.7(0.0-2.3)$ & $0.4 \pm 0.8(0.0-3.9)$ \\
\hline $\mathrm{Fe}$ & $109 \pm 69(45-346)$ & $25 \pm 8.2(15-38)$ & $26 \pm 7.5(15-52)$ \\
\hline $\mathrm{Zn}$ & $0.7 \pm 0.3(0.4-1.5)$ & $0.9 \pm 0.6(0.4-2.6)$ & $1.4 \pm 1.1(0.6-4.1)$ \\
\hline $\mathrm{Cr}$ & $0.22 \pm 0.12(0.10-0.65)$ & $0.09 \pm 0.04(0.00-0.18)$ & $0.10 \pm 0.03(0.03-0.16)$ \\
\hline $\mathrm{Ni}$ & $0.04 \pm 0.04(0.00-0.14)$ & $0.04 \pm 0.02(0.00-0.07)$ & $0.04 \pm 0.03(0.00-0.10)$ \\
\hline As & $0.03 \pm 0.05(0.00-0.23)$ & $0.01 \pm 0.02(0.00-0.07)$ & $0.04 \pm 0.07(0.00-0.27)$ \\
\hline $\mathrm{Br}$ & $0.00 \pm 0.00(0.00-0.02)$ & $0.02 \pm 0.03(0.00-0.11)$ & $0.030 \pm 0.04(0.00-0.15)$ \\
\hline Mo & $0.04 \pm 0.05(0.00-0.17)$ & $0.04 \pm 0.06(0.00-0.19)$ & $0.04 \pm 0.08(0.00-0.26)$ \\
\hline $\mathrm{Pb}$ & $0.37 \pm 0.19(0.09-0.77)$ & $0.39 \pm 0.15(0.20-0.71)$ & $0.39 \pm 0.12(0.14-0.65)$ \\
\hline Subtotal $^{\mathrm{a}}$ & $506 \pm 304(193-1559)$ & $148 \pm 42(92-225)$ & $191 \pm 43(136-335)$ \\
\hline \multicolumn{4}{|c|}{ IV. Other species in TSP samples, $\mu \mathrm{g} \mathrm{m}^{-3}$} \\
\hline WSOC & $15 \pm 10(4.2-52)$ & $15 \pm 17(2.0-58)$ & $19 \pm 11(7.8-49)$ \\
\hline WSIC & $10 \pm 2.8(6.8-20)$ & $5.9 \pm 3.3(1.9-13)$ & $6.0 \pm 1.7(2.9-9.5)$ \\
\hline WSIN & $4.2 \pm 1.0(2.4-6.5)$ & $5.2 \pm 1.2(3.6-8.0)$ & $12 \pm 1.3(9.1-14)$ \\
\hline WSON & $2.5 \pm 1.8(0.0-8.0)$ & $1.7 \pm 0.8(0.5-3.1)$ & $5.9 \pm 3.6(1.4-16)$ \\
\hline $\mathrm{OC}$ & $68 \pm 50(8.7-254)$ & $32 \pm 9.1(20-49)$ & $55 \pm 13(37-84)$ \\
\hline $\mathrm{EC}$ & $6.7 \pm 8.6(0.0-32)$ & $7.1 \pm 2.4(3.4-12)$ & $8.9 \pm 6.2(0.0-28)$ \\
\hline TSP & $2109 \pm 1360(774-7527)$ & $630 \pm 155(412-1037)$ & $687 \pm 194(476-1399)$ \\
\hline $\mathrm{PM}_{2.5} / \mathrm{TSP}, \%$ & $7.4 \pm 3.4(2.3-13)$ & $14 \pm 2.4(9.6-18)$ & $23 \pm 4.8(10-30)$ \\
\hline
\end{tabular}

${ }^{\text {a }}$ Calculated as $\mathrm{SO}_{4}^{2-}+\mathrm{Cl}^{-}+$metal oxides. 

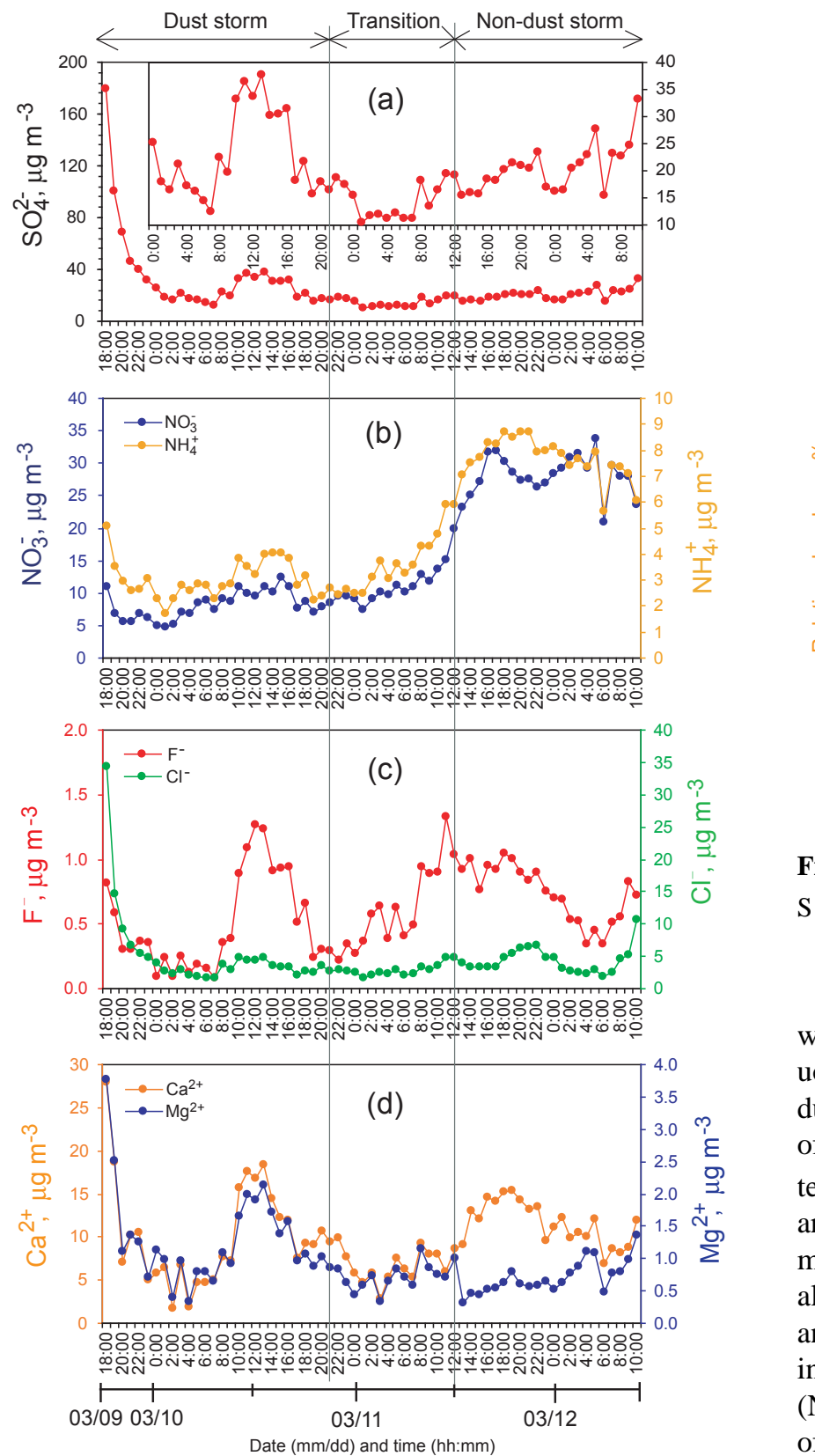

which are different from other ions and are almost continuously increasing from the dust storm period to the nondust-storm period (Fig. 4b). The temporal variation pattern of $\mathrm{Cl}^{-}$is similar to that of $\mathrm{SO}_{4}^{2-}$, while the variation pattern of $\mathrm{F}^{-}$is similar to $\mathrm{EC}$, indicating that $\mathrm{Cl}^{-}$and $\mathrm{SO}_{4}^{2-}$ are of similar natural origins but $\mathrm{F}^{-}$and $\mathrm{EC}$ are of common anthropogenic sources, e.g., coal combustion (Wang et al., 2010). There are many dried salt lakes in the northern and western parts of China and the Gobi area of Mongolia, in which halite $(\mathrm{NaCl})$, gypsum $\left(\mathrm{CaSO}_{4} \times 2 \mathrm{H}_{2} \mathrm{O}\right)$, mirabilite $\left(\mathrm{Na}_{2} \mathrm{SO}_{4} \times 10 \mathrm{H}_{2} \mathrm{O}\right)$ and other salts are common components of the surface soil (Zheng, 1991). Mineral species containing calcium and magnesium often coexist in desert regions.

Figure 4. Temporal variations of inorganic ions during the campaign.

As shown in Fig. 4a, extremely high levels of sulfate were observed during the dust storm period (Phase I), with a peak of $180 \mu \mathrm{g} \mathrm{m}^{-3}$ in the first hour, accounting for $2.3 \%$ of the TSP mass (Table 1), which falls in the range reported for the airborne dust in the Taklamakan desert by Wu et al (2012). Due to the second peak of the dust storm that arrived in Xi'an at noon on $10 \mathrm{March}, \mathrm{SO}_{4}^{2-}$ concentration showed a moderate peak as did TSP (see the inserted figure in Fig. 4a). During the whole sampling period, $\mathrm{NO}_{3}^{-}$ and $\mathrm{NH}_{4}^{+}$concentrations displayed similar variation patterns, For example, dolomite $\left(\mathrm{CaMg}\left(\mathrm{CO}_{3}\right)_{2}\right)$ is a common mineral salt in surface soil in the Taklamakan desert, Gobi desert and Loess Plateau of China (Li et al., 2007; Maher et al., 2009). Thus, both presented the same temporal pattern during the dust and transition periods when dust particles from the above regions are dominant (Fig. 4d). However, $\mathrm{Ca}^{2+}$ and $\mathrm{Mg}^{2+}$ displayed divergent patterns in the non-dust-storm period when the aerosols are dominated by local sources, indicating both ions are of different origins.

As seen in Fig. 5a, relative abundance of elemental calcium to TSP (Ca/TSP) during the whole sampling period was nearly constant, which slightly increased from $6.9 \pm 1.0 \%$ in the event to $8.2 \pm 1.4 \%$ in the non-event. In contrast, the ratio of $\mathrm{Ca}^{2+} / \mathrm{Ca}$ kept increasing from 


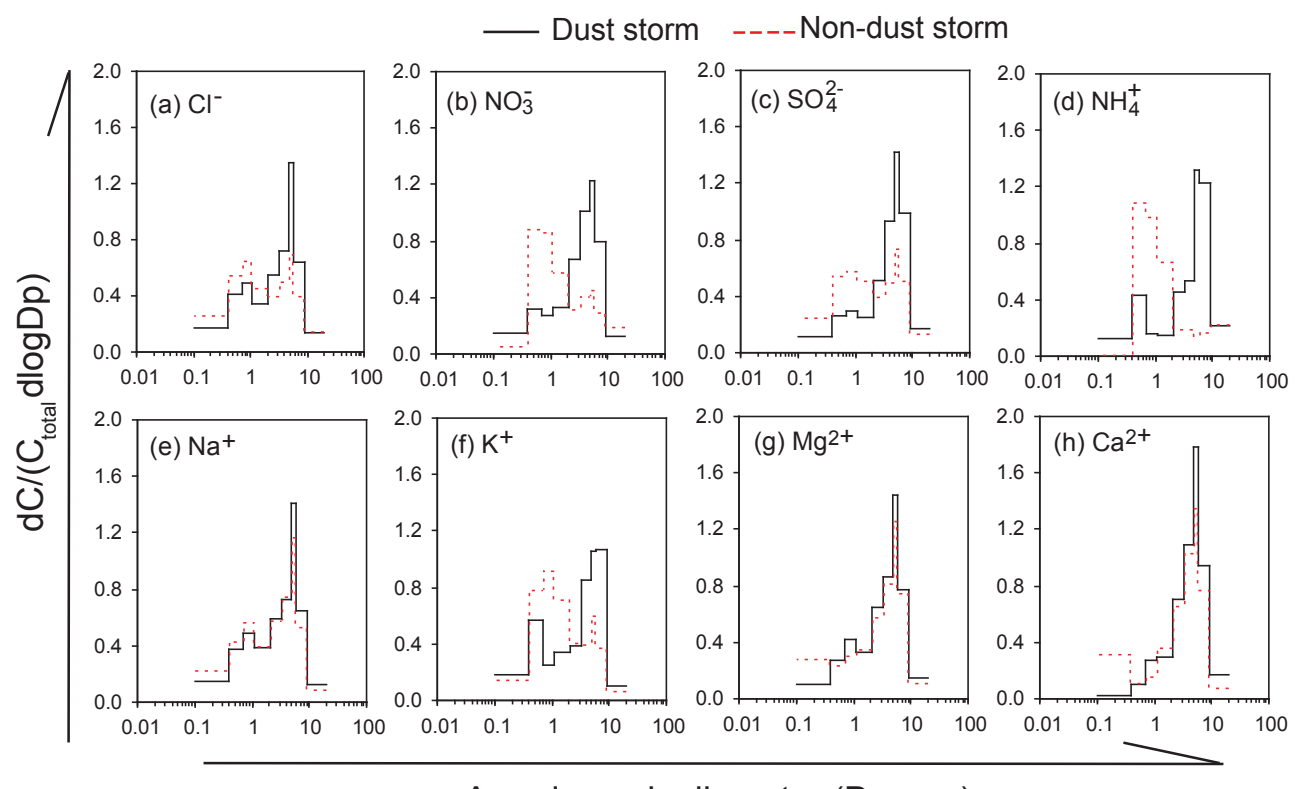

Aerodynamic diameter (Dp, $\mu \mathrm{m})$

Figure 6. Size distributions of major ions during the dust and non-dust-storm periods.

$7.1 \pm 2.8 \%$ in the event, to $16 \pm 6.0 \%$ in the transition period to $22 \pm 5.7 \%$ in the non-event, indicating an enrichment of local soil that consists of more water-soluble calcium and/or a continuous conversion of elemental calcium into calcium cation. Although the mass ratio of $\mathrm{SO}_{4}^{2-} / \mathrm{TSP}$ displayed an increasing trend from about $1.0 \%$ during the dust storm event to about $5.0 \%$ in the non-event, the ratios of $\mathrm{SO}_{4}^{2-}$ $\mathrm{S} /$ total-S in the TSP samples during the three periods are almost the same (Fig. 5b): $62 \pm 13 \%$ in the dust storm event, $61 \pm 6.1 \%$ in the transition time and $54 \pm 5.2 \%$, in the nonevent period, suggesting that sulfate in the samples is largely derived from dust/soil and photochemical production of sulfate was minor even in the non-dust period. Such a result is consistent with the observation for the dust storm during the spring of 2009 , by which we found only $12 \%$ of particulate sulfate in $\mathrm{Xi}^{\prime}$ an at that time was formed by secondary oxidation and $88 \%$ of the sulfate was transported from the desert region (Wang et al., 2013).

\subsection{Size distributions}

Size is an important parameter of an aerosol, which is related to its origin, formation pathway and composition (Hinds, 1999). To further investigate the chemical evolution process of the urban aerosols, size-resolved chemical compositions were analyzed for the dust storm and non-dust-storm periods. The size-segregated samples collected in the transition period were not used in this study because sampling duration of these samples overlapped somewhat with the non-dust period. As shown in Fig. $6 \mathrm{a}, \mathrm{Cl}^{-}$presented a bimodal pattern in the dust storm period with a large peak in the coarse mode $(>2.1 \mu \mathrm{m})$ and a minor peak in the fine mode $(<2.1 \mu \mathrm{m})$, in contrast to the case of the non-dust-storm period, which is characterized by two equivalent peaks in both the fine and the coarse modes. The pronounced coarse-mode peak in the dust storm period further suggests the origin of $\mathrm{NaCl}$ from dried salt lakes in the Gobi desert region. $\mathrm{NO}_{3}^{-}$and $\mathrm{SO}_{4}^{2-}$ dominated in the coarse mode when dust was present, but in the non-dust-storm period nitrate in the fine mode was much more abundant than in the coarse mode, while sulfate displayed two equivalent peaks in both modes (Fig. $6 \mathrm{~b}$ and c). The $\mathrm{SO}_{4}^{2-}$ distribution patterns in the dust storm and nondust-storm periods are similar to those of $\mathrm{Cl}^{-}$, while $\mathrm{NO}_{3}^{-}$ displayed similar patterns to those of $\mathrm{NH}_{4}^{+}$in both periods (Fig. 6b-d). During the non-dust-storm period $\mathrm{Cl}^{-}, \mathrm{NO}_{3}^{-}$and $\mathrm{SO}_{4}^{2-}$ in the fine mode $(<2.1 \mu \mathrm{m})$ accounted for 55,58 and $54 \%$ of the mass in the whole size range, respectively (Table 2 ); whereas in the dust event the fine modes of $\mathrm{Cl}^{-}, \mathrm{NO}_{3}^{-}$ and $\mathrm{SO}_{4}^{2-}$ decreased significantly, accounting for $40 \pm 4 \%$, $31 \pm 6 \%$ and $27 \pm 7 \%$ of the total, respectively (Table 2 ).

Size distribution patterns of $\mathrm{Na}^{+}$are almost identical with those of $\mathrm{Cl}^{-}$in both the dust and non-dust-storm periods (Fig. 6a and e), probably indicating that both ions have the same sources even in the non-dust-storm period. Apart from dried salt lakes, soil and seal salt, $\mathrm{Na}^{+}$and $\mathrm{Cl}^{-}$can also originate from biomass burning. For example, Andreae et al (1998) measured aerosol emissions from savanna fires in southern Africa and found that $\mathrm{Na}^{+}, \mathrm{Cl}^{-}$and $\mathrm{K}^{+}$were abundant in the smoke, with $40-90 \%$ of the mass distributing in particles with a diameter less than $1.2 \mu \mathrm{m} . \mathrm{K}^{+}$is generally considered a tracer of biomass burning smoke and enriched in fine particles (Andreae et al., 1998; Shen et al., 2007; Wang et al., 2012); thus the fine mode $(<2.1 \mu \mathrm{m})$ of 
Table 2. Accumulative percentages (\%) of mass concentrations of major ions on the nine-stage filters collected in Xi' an during the spring dust storm and non-dust-storm periods.

\begin{tabular}{|c|c|c|c|c|c|c|c|c|}
\hline Size range, $\mu \mathrm{m}$ & $\mathrm{Cl}^{-}$ & $\mathrm{NO}_{3}^{-}$ & $\mathrm{SO}_{4}^{2-}$ & $\mathrm{NH}_{4}^{+}$ & $\mathrm{Na}^{+}$ & $\mathrm{K}^{+}$ & $\mathrm{Mg}^{2+}$ & $\mathrm{Ca}^{2+}$ \\
\hline \multicolumn{9}{|c|}{ Dust storm period $(03 / 09,1800-03 / 10,2100)$} \\
\hline$>9.0$ & 100 & 100 & 100 & 100 & 100 & 100 & 100 & 100 \\
\hline $5.8-9.0$ & $86 \pm 1$ & $87 \pm 1$ & $83 \pm 3$ & $74 \pm 10$ & $87 \pm 1$ & $88 \pm 5$ & $85 \pm 2$ & $83 \pm 6$ \\
\hline $4.7-5.8$ & $74 \pm 2$ & $71 \pm 4$ & $64 \pm 5$ & $52 \pm 9$ & $75 \pm 2$ & $69 \pm 3$ & $70 \pm 3$ & $68 \pm 5$ \\
\hline $3.3-4.7$ & $62 \pm 2$ & $60 \pm 5$ & $51 \pm 5$ & $37 \pm 17$ & $62 \pm 3$ & $62 \pm 9$ & $57 \pm 2$ & $49 \pm 7$ \\
\hline $2.1-3.3$ & $51 \pm 2$ & $44 \pm 6$ & $37 \pm 7$ & $31 \pm 13$ & $51 \pm 3$ & $49 \pm 9$ & $43 \pm 3$ & $32 \pm 6$ \\
\hline $1.1-2.1$ & $40 \pm 4$ & $31 \pm 6$ & $27 \pm 7$ & $21 \pm 16$ & $39 \pm 4$ & $40 \pm 7$ & $31 \pm 3$ & $18 \pm 5$ \\
\hline $0.65-1.1$ & $31 \pm 4$ & $22 \pm 5$ & $20 \pm 6$ & $18 \pm 12$ & $28 \pm 3$ & $29 \pm 5$ & $22 \pm 3$ & $10 \pm 4$ \\
\hline $0.43-0.65$ & $21 \pm 2$ & $17 \pm 2$ & $14 \pm 4$ & $16 \pm 8$ & $19 \pm 3$ & $24 \pm 0$ & $14 \pm 3$ & $5 \pm 4$ \\
\hline$<0.43$ & $11 \pm 1$ & $9 \pm 1$ & $7 \pm 2$ & $9 \pm 5$ & $9 \pm 1$ & $11 \pm 1$ & $7 \pm 2$ & $2 \pm 2$ \\
\hline \multicolumn{9}{|c|}{ Non-dust-storm period $(03 / 11,1200-03 / 12,2100)$} \\
\hline$>9.0$ & 100 & 100 & 100 & 100 & 100 & 100 & 100 & 100 \\
\hline $5.8-9.0$ & 84 & 80 & 86 & 77 & 90 & 93 & 88 & 91 \\
\hline $4.7-5.8$ & 77 & 75 & 76 & 73 & 80 & 86 & 74 & 77 \\
\hline $3.3-4.7$ & 70 & 70 & 69 & 72 & 69 & 80 & 63 & 64 \\
\hline $2.1-3.3$ & 62 & 64 & 62 & 69 & 58 & 74 & 50 & 48 \\
\hline $1.1-2.1$ & 55 & 58 & 54 & 65 & 46 & 66 & 39 & 35 \\
\hline $0.65-1.1$ & 42 & 42 & 40 & 46 & 35 & 46 & 29 & 25 \\
\hline $0.43-0.65$ & 29 & 25 & 28 & 27 & 24 & 28 & 23 & 22 \\
\hline$<0.43$ & 16 & 3 & 15 & 1 & 13 & 9 & 17 & 19 \\
\hline
\end{tabular}

$\mathrm{K}^{+}$was relatively low in the dust storm period, accounting for $40 \pm 7 \%$ of the total mass in the whole size range, and became predominant in the non-dust-storm period, accounting for $66 \%$ of the total (Fig. $6 \mathrm{f}$ and Table 2). Such a result is consistent with the observation by Shen at al. (2008), which reported that $\mathrm{Cl}^{-}$and $\mathrm{K}^{+}$in the urban air of Xi'an are enriched in fine particles (i.e., $\mathrm{PM}_{2.5}$ ) and largely derived from extensively burning wheat straw and maize stalks by farmers in the suburban areas for cooking and heating. Since $\mathrm{Mg}^{2+}$ and $\mathrm{Ca}^{2+}$ are largely derived from soil, both dominated in the coarse mode during the dust and non-dust periods (Fig. $6 \mathrm{~g}$ and $h)$.

\subsection{Chemical forms, sources and productions of nitrate and sulfate}

Figure 7 shows the linear fit regressions for nitrate, sulfate, ammonium and other major cations in the TSP samples during the dust storm and transition periods. Nitrate showed a robust correlation with ammonium $\left(r^{2}=0.76\right.$, Fig. 7a) but presented no correlation with the sum of $\mathrm{Na}^{+}, \mathrm{K}^{+}, \mathrm{Mg}^{2+}$ plus $\mathrm{Ca}^{2+}$ (Fig. 7b). However, sulfate during the dust storm and transition periods were not correlated with ammonium but were strongly correlated with the sum of the above cations (Fig. 7c and d). Interestingly, robust linear correlations $\left(r^{2}>0.99\right)$ were found for the samples collected at the beginning $3 \mathrm{~h}$ (red dots in Fig. 7a-d), suggesting that dust particles in the city within this period are of the same chem-
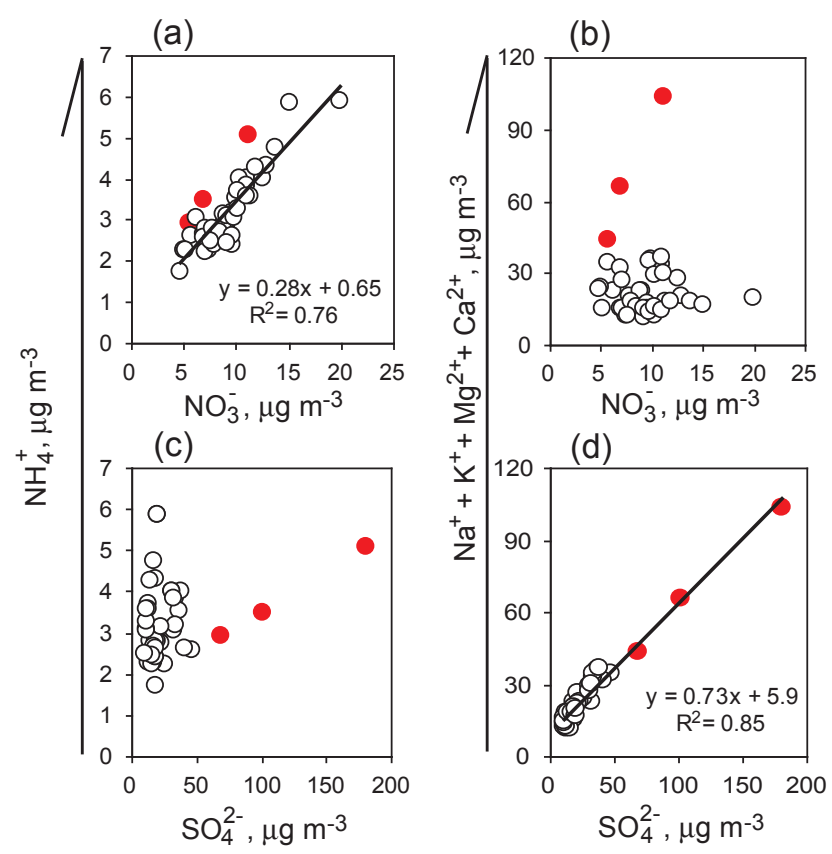

Figure 7. Linear fit regressions for nitrate and sulfate with ammonium and other cations in the TSP samples collected during the dust storm and transition periods (red dots are the three samples collected at the earliest $3 \mathrm{~h}$ ). 


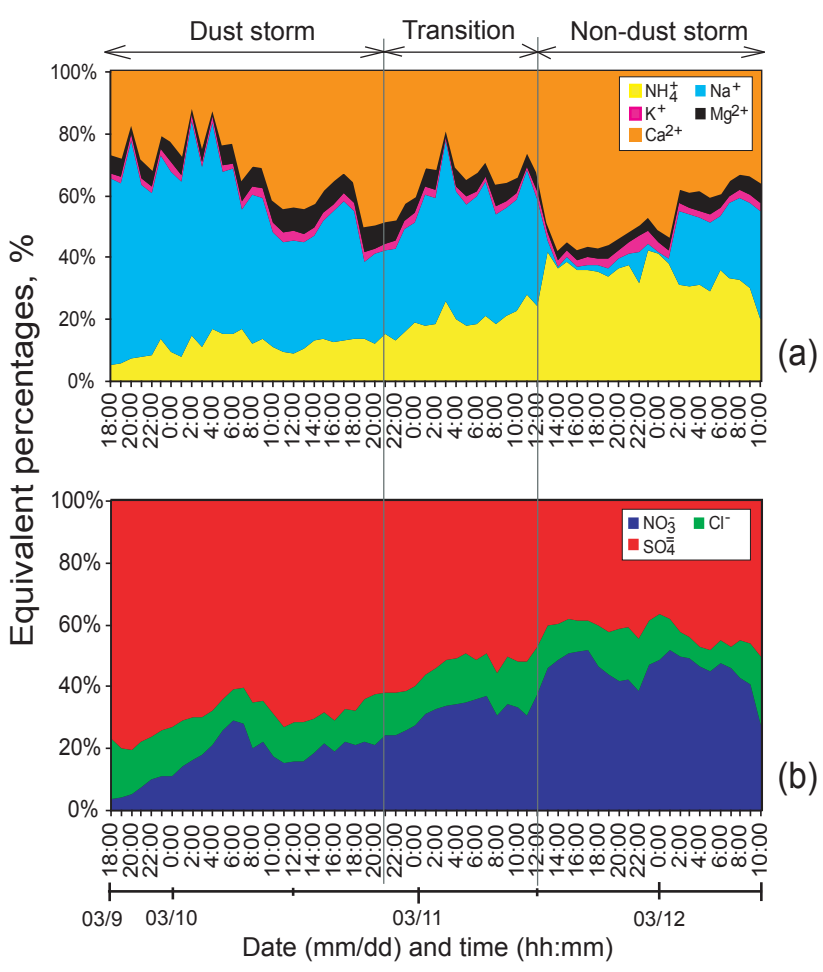

Figure 8. Equivalent percentages of inorganic ions in the TSP samples during the campaign.

ical compositions and are not chemically modified. Nitrate and ammonium mass concentrations not only displayed the similar size distribution patterns during the whole sampling period but were also strongly linearly correlated with each other during the dust storm and transition periods with a slope of 0.28 , which is equal to the $1: 1$ molar ratio of $\mathrm{NH}_{4}^{+}$ to $\mathrm{NO}_{3}^{-}$(Fig. 7a). Therefore, we assumed that $\mathrm{NH}_{4} \mathrm{NO}_{3}$ is the major chemical form of both ions in the airborne particles, especially in the dust storm and transition periods. Equivalent percentages showed that $\mathrm{Na}^{+}$and $\mathrm{Ca}^{2+}$ are the two major cations during the dust storm and transition periods, accounting for $77 \pm 5.0 \%$ (range, $65-87 \%$ ) of the total cation equivalent (Fig. 8a). Nitrate and sulfate are the two major anions, accounting for $86 \pm 2.1 \%$ (range, $80-90 \%$ ) of the total anion equivalent (Fig. 8b). As discussed above, $\mathrm{NaCl}$ and $\mathrm{NH}_{4} \mathrm{NO}_{3}$ are the major chemical forms of $\mathrm{Cl}^{-}$and $\mathrm{NO}_{3}^{-}$in the TSP samples, respectively. Thus, it is reasonably expected that the remaining $\mathrm{Na}^{+}$and other major cations in the samples exist as sulfate salts (i.e., $\mathrm{Na}_{2} \mathrm{SO}_{4}, \mathrm{CaSO}_{4}$, $\mathrm{MgSO}_{4}$ and $\mathrm{K}_{2} \mathrm{SO}_{4}$ ) during the dust storm and transition periods. Concentrations of these sulfate salts during the dust and transition periods and their relative abundances to the total sulfate in the water-soluble fraction are summarized in Table 3 and shown in Fig. 9. Within these periods $\mathrm{Na}_{2} \mathrm{SO}_{4}$ and $\mathrm{CaSO}_{4}$ are the major sulfate salts, which originate from dust source regions and account for more than $90 \%$ of the total water-soluble sulfate salts.

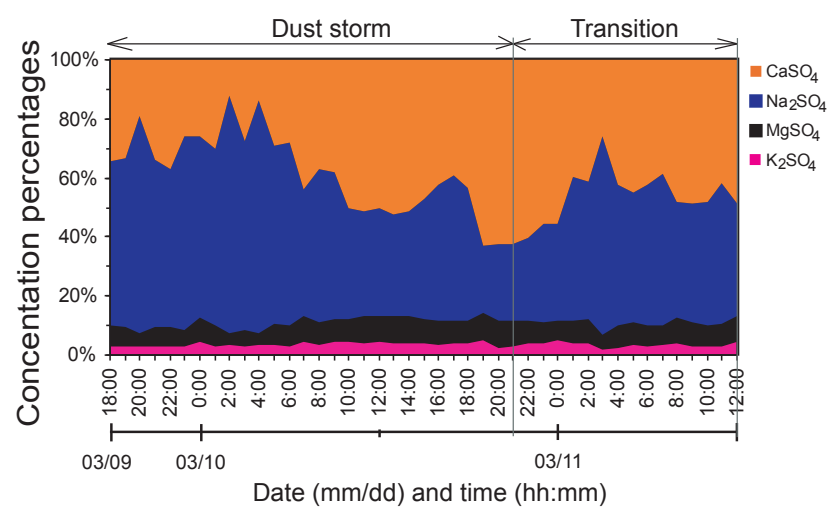

Figure 9. Chemical forms of water-soluble sulfate salts in the TSP samples during the dust storm and transition periods.

Figure 10a shows a temporal variation in molar ratio of $\mathrm{NO}_{3}^{-} / \mathrm{SO}_{4}^{2-}$ during the whole period. Because nitrate in Gobi desert surface soil is much less than sulfate, the molar ratio of $\mathrm{NO}_{3}^{-}$to $\mathrm{SO}_{4}^{2-}$ in the beginning hours was $<0.1$ and gradually increased up to 2.8 along with an increase in the observation time (see Fig. 10a), indicating that the heterogeneous formation of $\mathrm{NO}_{3}^{-}$on dust surface is much faster than $\mathrm{SO}_{4}^{2-}$. For example, during the nighttime of 9 and 10 March molar ratio of $\mathrm{NO}_{3}^{-} / \mathrm{SO}_{4}^{2-}$ increased by a rate of $0.07 \mathrm{~h}^{-1}$ (Fig. 10b). As discussed above, dust particles in the first $3 \mathrm{~h}$ during the dust storm period were not chemically modified, and EC at that time was zero. Thus, here we use the first sample as a reference to calculate the heterogeneous productions of $\mathrm{NO}_{3}^{-}$, $\mathrm{SO}_{4}^{2-}$ and $\mathrm{NH}_{4}^{+}$for the remaining TSP samples by using the following equation:

$\mathrm{d} A=\mathrm{C}_{A}^{i}-\frac{\mathrm{C}_{A}^{\mathrm{ref}}}{\mathrm{C}_{\mathrm{TSP}}^{\mathrm{ref}}} \cdot \mathrm{C}_{\mathrm{TSP}}^{i}$

where $\mathrm{dA}$ is the secondarily formed $\mathrm{NO}_{3}^{-}, \mathrm{SO}_{4}^{2-}$ or $\mathrm{NH}_{4}^{+}$in the sample $i ; \mathrm{C}_{A}^{i}$ is the concentration of $\mathrm{NO}_{3}^{-}, \mathrm{SO}_{4}^{2-}$ or $\mathrm{NH}_{4}^{+}$ in the sample $\mathrm{i} ; \mathrm{C}_{A}^{\text {ref }}$ is the concentration of $\mathrm{NO}_{3}^{-}, \mathrm{SO}_{4}^{2-}$ or $\mathrm{NH}_{4}^{+}$in the first sample at the beginning hour of the dust storm period; $\mathrm{C}_{\mathrm{TSP}}^{\text {ref }}$ is the TSP concentration of the first sample; and $\mathrm{C}_{\mathrm{TSP}}^{i}$ is the TSP concentration of the sample $i$.

The calculated results - i.e., $\mathrm{dNO}_{3}^{-}, \mathrm{dSO}_{4}^{2-}$ and $\mathrm{dNH}_{4}^{+}-$ are produced by heterogeneous reactions of $\mathrm{HNO}_{3}(\mathrm{~g}), \mathrm{NO}_{\mathrm{x}}$, $\mathrm{SO}_{2}$ and $\mathrm{NH}_{3}$ on the dust surface and are normalized by the total. As seen in Fig. 11, $\mathrm{dNO}_{3}^{-} /$total $\mathrm{NO}_{3}^{-}$and $\mathrm{dNH}_{4}^{+} /$total $\mathrm{NH}_{4}^{+}$presented identical variation patterns with a sharp increase from less than 0.1 to 0.9 in the dust storm and transition periods to above 0.9 in the non-dust period. However, the ratio of $\mathrm{dSO}_{4}^{2-}$ / total $\mathrm{SO}_{4}^{2-}$ is almost zero in the dust storm and transition periods and increased to about 0.4 during the late hours of the non-dust-storm period. Such phenomena again demonstrate that nitrate and ammonium in the airborne particles during the whole campaign existed as the chemical form of $\mathrm{NH}_{4} \mathrm{NO}_{3}$, and its production speed is much 
Table 3. Concentrations $\left(\mu \mathrm{g} \mathrm{m}^{-3}\right)$ of different sulfates in the water-soluble fraction of TSP samples and their relative abundances $(\%)$ to the total water-soluble sulfate during the dust storm and transition periods.

\begin{tabular}{llllll}
\hline & & $\mathrm{K}_{2} \mathrm{SO}_{4}$ & $\mathrm{MgSO}_{4}$ & $\mathrm{Na}_{2} \mathrm{SO}_{4}$ & $\mathrm{CaSO}_{4}$ \\
\hline $\begin{array}{l}\text { Dust storm } \\
\text { period }\end{array}$ & Concentration, & $3.4 \pm 1.7(1.6-9.2)$ & $13 \pm 7.1(3.3-38)$ & $45 \pm 30(11-155)$ & $35 \pm 20(5.8-95)$ \\
& $\begin{array}{l}\text { Relative } \\
\text { abundance }\end{array}$ & $3.6 \pm 0.7(2.5-4.7)$ & $13 \pm 2.6(7.0-17)$ & $47 \pm 15(21-77)$ & $36 \pm 12(12-58)$ \\
\hline $\begin{array}{l}\text { Transition } \\
\text { period }\end{array}$ & Concentration & $1.9 \pm 0.5(0.8-2.8)$ & $7.2 \pm 2.0(3.3-11)$ & $21 \pm 4.0(12-25)$ & $23 \pm 6.5(10-33)$ \\
& $\begin{array}{l}\text { Relative } \\
\text { abundance }\end{array}$ & $3.0 \pm 0.8(2-5)$ & $13 \pm 1.8(9-16)$ & $41 \pm 9.0(26-64)$ & $42 \pm 7.6(25-56)$ \\
\hline
\end{tabular}
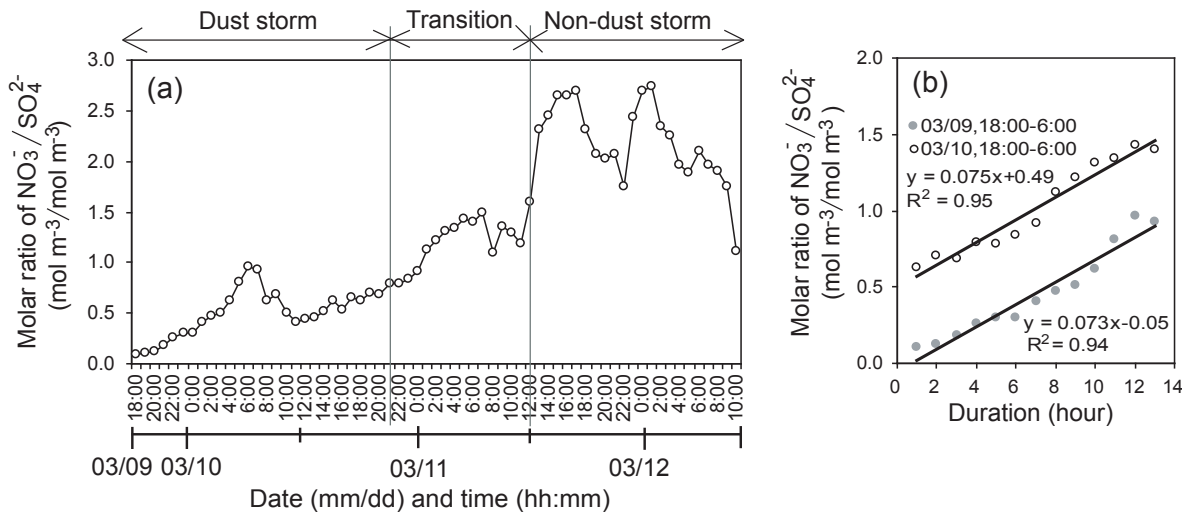

Figure 10. Production speed of nitrate during the sampling period, (a) molar ratio of nitrate/sulfate in the TSP samples and (b) linear fit regression for the nighttime molar ratio of nitrate/ sulfate with observation duration.

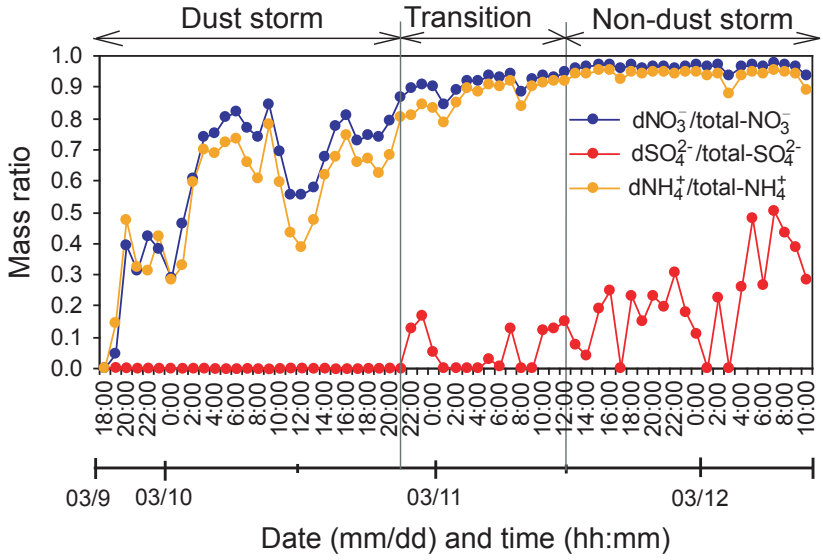

Figure 11. Mass ratios of nitrate, sulfate and ammonium produced by heterogeneous reactions to the totals in the TSP samples.

faster than sulfate. In the dust storm period $\mathrm{SO}_{4}^{2-}$ almost entirely originated from surface soil in the Gobi desert, and no significant amount of $\mathrm{SO}_{4}^{2-}$ in the dust storm event was secondarily produced (Fig. 11).
Hygroscopicity of the ambient aerosols during the whole campaign was also investigated by determining the hygroscopic growth factor of the water-soluble fraction of the TSP samples (Huang and Wang, 2014). The results showed that the $\kappa$ value of the water-soluble fraction of dust particles ranged from 0.20 to $0.38(0.30 \pm 0.04)$, indicating a wettable nature of the dust particles (Andreae and Rosenfeld, 2008). Here, we propose a three-step mechanism of heterogeneous formation of nitrate on dust surface to explain the above secondary formation of $\mathrm{NH}_{4} \mathrm{NO}_{3}$ (see Fig. 12). As discussed above, the airborne particles during the dust storm and transition period consist of significant amounts of water-soluble $\mathrm{NaCl}$ and $\mathrm{Na}_{2} \mathrm{SO}_{4}$. These compounds are very hygroscopic and thus may take up water vapor, forming a liquid phase on the dust surface even under the low-RH conditions of the dust storm period ( $\mathrm{RH}=22 \pm 3.5 \%$, Table 1$)$. The aqueous phase is favorable for the formation of $\mathrm{NH}_{4} \mathrm{NO}_{3}$, which is probably formed via a gas-phase homogeneous reaction of nitric acid with ammonia and a subsequent partitioning into the liquid phase (Nie et al., 2012; Pathak et al., 2011). In addition, $\mathrm{NO}_{3}^{-}$can also be produced in the liquid phase via heterogeneous reactions of gaseous $\mathrm{HNO}_{3}, \mathrm{~N}_{2} \mathrm{O}_{5}$ and $\mathrm{NO}_{\mathrm{x}}$ with dust particles (Finlayson-Pitts et al., 2003; Hanisch and Crowley, 2001; Laskin et al., 2005; Usher et al., 2003), 


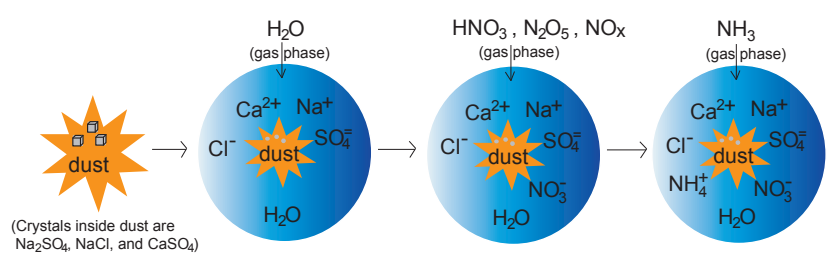

Figure 12. A diagram for heterogeneous formation mechanism of ammonium nitrate on dust surface in Xi' an during the dust storm event.

followed by a subsequent absorption of the gas-phase $\mathrm{NH}_{3}$ to form $\mathrm{NH}_{4} \mathrm{NO}_{3}$ (as illustrated by Fig. 12). As a result, an enrichment of $\mathrm{NH}_{4}^{+}$in the coarse mode $(>2.1 \mu \mathrm{m})$ was observed during the dust storm and transition period when dust particles were dominant (Fig. 6). These kinds of phenomena are different from the cases of the East Asia continental outflow region, including the Sea of Japan (Massling, et al., 2007), North Pacific (Sullivian et al., 2007) and western North America (Fairlie et al., 2010), where in the presence of Asian dust ammonium is often enriched in fine particles as ammonium sulfate and/or ammonium bisulfate, which are formed by heterogeneous reactions of sulfuric acid with ammonia, although nitrate is still in the coarse mode. Such differences indicate an infant state of chemical evolution of dust particles in Xi' an, which is near the dust source regions.

\section{Summary and conclusions}

High time resolution of TSP and size-resolved samples in Xi'an, inland China, during a dust episode occurring in March of 2013 were collected and categorized into three groups - i.e., dust storm, transition and non-dust-storm samples - based on the TSP levels and air parcel movement tracks. Nitrate in the TSP samples only showed a strong linear correlation with ammonium during the whole sampling period. Contrarily, $\mathrm{SO}_{4}^{-}$and $\mathrm{Cl}^{-}$were well correlated with $\mathrm{Na}^{+}, \mathrm{Ca}^{2+}, \mathrm{Mg}^{2+}$ and $\mathrm{K}^{+}$but not correlated with ammonium, especially in the dust storm and transition periods. The size distribution pattern of $\mathrm{NO}_{3}^{-}$is similar to that of $\mathrm{NH}_{4}^{+}$, which presented a bimodal pattern with a dominant peak in the coarse mode when the dust storm occurred and with a predominant peak in the fine mode in the absence of the dust storm. In the event size distribution patterns, $\mathrm{Cl}^{-}$and $\mathrm{SO}_{4}^{-}$ are similar to those of $\mathrm{Na}^{+}, \mathrm{Ca}^{2+}, \mathrm{Mg}^{2+}$ and $\mathrm{K}^{+}$, dominating in the coarse mode. During the non-event, $\mathrm{Cl}^{-}, \mathrm{K}^{+}$and $\mathrm{SO}_{4}^{-}$showed an increase in the fine mode due to enhancements of biomass burning emission and secondary oxidation. Based on the above correlations and size distribution pattern, we assumed that $\mathrm{NO}_{3}^{-}, \mathrm{SO}_{4}^{2-}$ and $\mathrm{Cl}^{-}$in the airborne particles during the whole campaign possibly existed as $\mathrm{NH}_{4} \mathrm{NO}_{3}, \mathrm{Na}_{2} \mathrm{SO}_{4}, \mathrm{CaSO}_{4}, \mathrm{MgSO}_{4}, \mathrm{~K}_{2} \mathrm{SO}_{4}$ and $\mathrm{NaCl}$. The molar ratio of $\mathrm{NO}_{3}^{-} / \mathrm{SO}_{4}^{2-}$ was observed to continuously increase from less than 0.1 at the moment of the dust storm peak arrived in the city to about 2.5 during the non-duststorm event, demonstrating that nitrate production is much faster than sulfate. Secondarily produced $\mathrm{NH}_{4}^{+}$and $\mathrm{NO}_{3}^{-}$accounted for $54 \pm 20 \%$ and $60 \pm 23 \%$ of the total in the dust storm period, $87 \pm 4.0 \%$ and $91 \pm 3.0 \%$ of the total in the transition period, and $94 \pm 2.0 \%$ and $96 \pm 1.0 \%$ of the total in the non-dust-storm period. In contrast, secondarily produced $\mathrm{SO}_{4}^{2-}$ is almost zero in the dust storm period and accounted for $5.0 \pm 6.0 \%$ of the total at the transition time and $21 \pm 15 \%$ of the total in the non-dust-storm period. Sulfate in the dust storm period is almost entirely transported from Gobi desert surface soil as chemical forms of $\mathrm{Na}_{2} \mathrm{SO}_{4}$ and $\mathrm{CaSO}_{4}$, which are common minerals in the desert region. Our observation results also indicate that, in the presence of East Asia dust storm, particles that contain hygroscopic $\mathrm{NaCl}$ and $\mathrm{Na}_{2} \mathrm{SO}_{4}$ can take up water vapor and form a liquid phase on the particle surface, which results in the formation of nitrate and the subsequent absorption of ammonia to form $\mathrm{NH}_{4} \mathrm{NO}_{3}$. Therefore, a coarse mode of $\mathrm{NH}_{4}^{+}$was observed during the dust storm period. These phenomena not only demonstrate a faster production of nitrate than sulfate but also indicate an infant state of chemical evolution of East Asian dust particles in the regions near the source.

Acknowledgements. This work was financially supported by China National Science Funds for Distinguished Young Scholars (grant no. 41325014) and the "Strategic Priority Research Program" of the Chinese Academy of Sciences (grant no. XDA05100103, XDB05020401)

Edited by: X. Tie

\section{References}

Andreae, M. O., Andreae, T. W., Annegarn, H., Beer, J., Cachier, H., leCanut, P., Elbert, W., Maenhaut, W., Salma, I., Wienhold, F. G., and Zenker, T.: Airborne studies of aerosol emissions from savanna fires in southern Africa: 2. Aerosol chemical composition, J. Geophys. Res., 103, doi:10.1029/1098JD00107, 3211932128, 1998.

Andreae, M. O. and Rosenfeld, D.: Aerosol-cloud-precipitation interactions. Part 1. The nature and sources of cloud-active aerosols, Earth-Sci. Rev., 89, 13-41, 2008.

Arimoto, R., Zhang, X. Y., Huebert, B. J., Kang, C. H., Savoie, D. L., Prospero, J. M., Sage, S. K., Schloesslin, C. A., Khaing, H. M., and Oh, S. N.: Chemical composition of atmospheric aerosols from Zhenbeitai, China, and Gosan, South Korea, during ACE-Asia, J. Geophys. Res.-Atmos., 109, D19S04, doi:10.1029/2003JD004323, 2004.

Arimoto, R., Kim, Y. J., Kim, Y. P., Quinn, P. K., Bates, T. S., Anderson, T. L., Gong, S., Uno, I., Chin, M., Huebert, B. J., Clarke, A. D., Shinozuka, Y., Weber, R. J., Anderson, J. R., Guazzotti, S. A., Sullivan, R. C., Sodeman, D. A., Prather, K. A., and Sokolik, I. N.: Characterization of Asian Dust during ACE-Asia, Global Planet. Change, 52, 23-56, 2006. 
Boreddy, S. K. R., Kawamura, K., and Jung, J.: Hygroscopic properties of particles nebulized from water extracts of aerosols collected at Chichijima Island in the western North Pacific: an outflow region of Asian dust, J. Geophys. Res.-Atmos., 119, 167178, doi:10.1002/2013JD020626, 2014.

Boyd, P. W., Jickells, T., Law, C. S., Blain, S., Boyle, E. A., Buesseler, K. O., Coale, K. H., Cullen, J. J., de Baar, H. J. W., Follows, M., Harvey, M., Lancelot, C., Levasseur, M., Owens, N. P. J., Pollard, R., Rivkin, R. B., Sarmiento, J., Schoemann, V., Smetacek, V., Takeda, S., Tsuda, A., Turner, S., and Watson, A. J.: Mesoscale Iron Enrichment Experiments 19932005: synthesis and future directions, Science, 315, 612-617, 2007.

Buseck, P. R. and Pósfai, M.: Airborne minerals and related aerosol particles: effects on climate and the environment, P. Natl. Acad. Sci. USA, 96, 3372-3379, 1999.

Cape, J. N., Cornell, S. E., Jickells, T. D., and Nemitz, E.: Organic nitrogen in the atmosphere - where does it come from? A review of sources and methods, Atmos. Res., 102, 30-48, 2011.

Chen, H. Y., Chen, L. D., Chiang, Z. Y., Hung, C. C., Lin, F. J., Chou, W. C., Gong, G. C., and Wen, L. S.: Size fractionation and molecular composition of water-soluble inorganic and organic nitrogen in aerosols of a coastal environment, J. Geophys. Res.Atmos., 115, D22307, doi:10.1029/2010JD014157, 2010.

China Statistical Press: China Statistical Yearbook, edited, Chinese Statistics Press, Beijing, 2012.

Creamean, J. M., Suski, K. J., Rosenfeld, D., Cazorla, A., DeMott, P. J., Sullivan, R. C., White, A. B., Ralph, F. M., Minnis, P., Comstock, J. M., Tomlinson, J. M., and Prather, K. A.: Dust and biological aerosols from the Sahara and Asia influence precipitation in the western U.S., Science, 339, 1572-1578, 2013.

Dentener, F. J., Carmichael, G. R., Zhang, Y., Lelieveld, J., and Crutzen, P. J.: Role of mineral aerosol as a reactive surface in the global troposphere, J. Geophys. Res., 101, 22869-22889, 1996.

Dentener, F., Kinne, S., Bond, T., Boucher, O., Cofala, J., Generoso, S., Ginoux, P., Gong, S., Hoelzemann, J. J., Ito, A., Marelli, L., Penner, J. E., Putaud, J.-P., Textor, C., Schulz, M., van der Werf, G. R., and Wilson, J.: Emissions of primary aerosol and precursor gases in the years 2000 and 1750 prescribed data-sets for AeroCom, Atmos. Chem. Phys., 6, 4321-4344, doi:10.5194/acp-64321-2006, 2006.

Duce, R. A., LaRoche, J., Altieri, K., Arrigo, K. R., Baker, A. R., Capone, D. G., Cornell, S., Dentener, F., Galloway, J., Ganeshram, R. S., Geider, R. J., Jickells, T., Kuypers, M. M., Langlois, R., Liss, P. S., Liu, S. M., Middelburg, J. J., Moore, C. M., Nickovic, S., Oschlies, A., Pedersen, T., Prospero, J., Schlitzer, R., Seitzinger, S., Sorensen, L. L., Uematsu, M., Ulloa, O., Voss, M., Ward, B., and Zamora, L.: Impacts of atmospheric anthropogenic nitrogen on the open ocean, Science, 320, 893-897, doi:10.1126/science.1150369, 2008.

Fairlie, T. D., Jacob, D. J., Dibb, J. E., Alexander, B., Avery, M. A., van Donkelaar, A., and Zhang, L.: Impact of mineral dust on nitrate, sulfate, and ozone in transpacific Asian pollution plumes, Atmos. Chem. Phys., 10, 3999-4012, doi:10.5194/acp-10-39992010, 2010.

Finlayson-Pitts, B. J., Wingen, L. M., Sumner, A. L., Syomin, D., and Ramazan, K. A.: The heterogeneous hydrolysis of $\mathrm{NO}_{2}$ in laboratory systems and in outdoor and indoor atmospheres: an integrated mechanism, Phys. Chem. Chem. Phys., 5, 223-242, 2003.

Formenti, P., Schütz, L., Balkanski, Y., Desboeufs, K., Ebert, M., Kandler, K., Petzold, A., Scheuvens, D., Weinbruch, S., and Zhang, D.: Recent progress in understanding physical and chemical properties of African and Asian mineral dust, Atmos. Chem. Phys., 11, 8231-8256, doi:10.5194/acp-11-8231-2011, 2011.

Geng, H., Hwang, H., Liu, X., Dong, S., and Ro, C.-U.: Investigation of aged aerosols in size-resolved Asian dust storm particles transported from Beijing, China, to Incheon, Korea, using low- $Z$ particle EPMA, Atmos. Chem. Phys., 14, 3307-3323, doi:10.5194/acp-14-3307-2014, 2014.

Ginoux, P., Chin, M., Tegen, I., Prospero, J. M., Holben, B., Dubovik, O., and Lin, S.-J.: Sources and distributions of dust aerosol simulated with the GOCART model, J. Geophys. Res.Atmos., 106, 20255-20273, 2001.

Grassian, V. H.: Heterogeneous uptake and reaction of nitrogen oxides and volatile organic compounds on the surface of atmospheric particles including oxides, carbonates, soot and mineral dust: implications for the chemical balance of the troposphere, Int. Rev. Phys. Chem., 20, 467-548, 2001.

Hanisch, F. and Crowley, J. N.: The heterogeneous reactivity of gaseous nitric acid on authentic mineral dust samples, and on individual mineral and clay mineral components, Phys. Chem. Chem. Phys., 3, 2474-2482, 2001.

$\mathrm{He}, \mathrm{H}$.: Mineral dust and $\mathrm{NO}_{\mathrm{x}}$ promote the conversion of $\mathrm{SO}_{2}$ to sulfate in heavy pollution days, Scientific Reports, 4, 4172-4176, 2014.

Hinds, W. C.: Aerosol Technology: Properties, Behavior, and Measurement of Airborne Particles, John Willy \& Sons, New York, 1999.

Huang, Y. and Wang, G. H.: Hourly variations of composition and hygroscopicity of ambient particles in Xi'an during dust storm periods, J. Earth Environ., in review, 2014. (in Chinese)

Huang, K., Zhuang, G., Li, J., Wang, Q., Sun, Y., Lin, Y., and Fu, J. S.: Mixing of Asian dust with pollution aerosol and the transformation of aerosol components during the dust storm over China in spring 2007, J. Geophys. Res.-Atmos., 115, D00K13, doi:10.1029/2009JD013145, 2010.

Huang, K., Zhuang, G., Wang, Q., Fu, J. S., Lin, Y., Liu, T., Han, L., and Deng, C.: Extreme haze pollution in Beijing during January 2013: chemical characteristics, formation mechanism and role of fog processing, Atmos. Chem. Phys. Discuss., 14, 7517-7556, doi:10.5194/acpd-14-7517-2014, 2014.

Huebert, B. J., Bates, T., Russell, P. B., Shi, G. Y., Kim, Y. J., Kawamura, K., Carmichael, G., and Nakajima, T.: An overview of ACE-Asia: strategies for quantifying the relationships between Asian aerosols and their climatic impacts, J. Geophys. Res.Atmos., 108, 8663, doi:10.1029/2003JD003550, 2003.

Jickells, T. D., An, Z. S., Andersen, K. K., Baker, A. R., Bergametti, G., Brooks, N., Cao, J. J., Boyd, P. W., Duce, R. A., Hunter, K. A., Kawahata, H., Kubilay, N., laRoche, J., Liss, P. S., Mahowald, N., Prospero, J. M., Ridgwell, A. J., Tegen, I., and Torres, R.: Global iron connections between desert dust, ocean biogeochemistry, and climate, Science, 308, 67-71, 2005.

Kanakidou, M., Duce, R. A., Prospero, J. M., Baker, A. R., BenitezNelson, C., Dentener, F. J., Hunter, K. A., Liss, P. S., Mahowald, N., Okin, G. S., Sarin, M., Tsigaridis, K., Uematsu, M., Zamora, L. M., and Zhu, T.: Atmospheric fluxes of organic $\mathrm{N}$ 
and $\mathrm{P}$ to the global ocean, Global Biogeochem. Cy., 26, GB3026, doi:10.1029/2011GB004277, 2012.

Kim, Y. S., Iwasaka, Y., Shi, G. Y., Nagatani, T., Shibata, T., Trochkin, D., Matsuki, A., Yamada, M., Chen, B., Zhang, D., Nagatani, M., and Nakata, H.: Dust particles in the free atmosphere over desert areas on the Asian continent: measurements from summer 2001 to summer 2002 with balloon-borne optical particle counter and lidar, Dunhuang, China, J. Geophys. Res.Atmos., 109, D19S26, doi:10.1029/2002JD003269, 2004.

Laskin, A., Wietsma, T. W., Krueger, B. J., and Grassian, V. H.: Heterogeneous chemistry of individual mineral dust particles with nitric acid: a combined CCSEM/EDX, ESEM, and ICP-MS study, J. Geophys. Res.-Atmos., 110, D10208, doi:10210.11029/12004JD005206, 2005.

Laurent, B., Marticorena, B., Bergametti, G., and Mei, F.: Modeling mineral dust emissions from Chinese and Mongolian deserts, Global Planet. Change, 52, 121-141, 2006.

Leaitch, W. R., Macdonald, A. M., Anlauf, K. G., Liu, P. S. K., Toom-Sauntry, D., Li, S.-M., Liggio, J., Hayden, K., Wasey, M. A., Russell, L. M., Takahama, S., Liu, S., van Donkelaar, A., Duck, T., Martin, R. V., Zhang, Q., Sun, Y., McKendry, I., Shantz, N. C., and Cubison, M.: Evidence for Asian dust effects from aerosol plume measurements during INTEX-B 2006 near Whistler, BC, Atmos. Chem. Phys., 9, 3523-3546, doi:10.5194/acp-9-3523-2009, 2009.

Li, G., Chen, J., Chen, Y., Yang, J., Ji, J., and Liu, L.: Dolomite as a tracer for the source regions of Asian dust, J. Geophys. Res.Atmos., 112, D17201, doi:10.1029/2007JD008676, 2007.

Li, W. J. and Shao, L. Y.: Observation of nitrate coatings on atmospheric mineral dust particles, Atmos. Chem. Phys., 9, 18631871, doi:10.5194/acp-9-1863-2009, 2009.

Li, W., Shao, L., Shi, Z., Chen, J., Yang, L., Yuan, Q., Yan, C., Zhang, X., Wang, Y., Sun, J., Zhang, Y., Shen, X., Wang, Z., and Wang, W.: Mixing state and hygroscopicity of dust and haze particles before leaving Asian continent, J. Geophys. Res.-Atmos., 119, 1044-1059, 2014.

Liu, T.: Loess in China, China Ocean Press, Beijing, 1985.

Lu, Z., Streets, D. G., Zhang, Q., Wang, S., Carmichael, G. R., Cheng, Y. F., Wei, C., Chin, M., Diehl, T., and Tan, Q.: Sulfur dioxide emissions in China and sulfur trends in East Asia since 2000, Atmos. Chem. Phys., 10, 6311-6331, doi:10.5194/acp-106311-2010, 2010.

Maher, B. A., Mutch, T. J., and Cunningham, D.: Magnetic and geochemical characteristics of Gobi Desert surface sediments: implications for provenance of the Chinese Loess Plateau, Geology, 37, 279-282, 2009.

Manktelow, P. T., Carslaw, K. S., Mann, G. W., and Spracklen, D. V.: The impact of dust on sulfate aerosol, $\mathrm{CN}$ and $\mathrm{CCN}$ during an East Asian dust storm, Atmos. Chem. Phys., 10, 365-382, doi:10.5194/acp-10-365-2010, 2010.

Massling, A., Leinert, S., Wiedensohler, A., and Covert, D.: Hygroscopic growth of sub-micrometer and one-micrometer aerosol particles measured during ACE-Asia, Atmos. Chem. Phys., 7, 3249-3259, doi:10.5194/acp-7-3249-2007, 2007.

McNaughton, C. S., Clarke, A. D., Kapustin, V., Shinozuka, Y., Howell, S. G., Anderson, B. E., Winstead, E., Dibb, J., Scheuer, E., Cohen, R. C., Wooldridge, P., Perring, A., Huey, L. G., Kim, S., Jimenez, J. L., Dunlea, E. J., DeCarlo, P. F., Wennberg, P. O., Crounse, J. D., Weinheimer, A. J., and Flocke, F.: Observations of heterogeneous reactions between Asian pollution and mineral dust over the Eastern North Pacific during INTEX-B, Atmos. Chem. Phys., 9, 8283-8308, doi:10.5194/acp-9-8283-2009, 2009.

Menon, S., Unger, N., Koch, D., Francis, J., Garrett, T., Sednev, I., Shindell, D., and Streets, D.: Aerosol climate effects and air quality impacts from 1980 to 2030, Environ. Res. Lett., 3, 024004, doi:10.1088/1748-9326/3/2/024004, 2008.

Mochida, M., Umemoto, N., Kawamura, K., Lim, H., and Turpin, B. J.: Bimodal size distributions of various organic acids and fatty acids in the marine atmosphere: influence of anthropogenic aerosols, Asian dusts, and sea spray off the coast of East Asia, J. Geophys. Res., 112, D15209, doi:10.1029/2006JD007773, 2007.

Mogili, P. K., Kleiber, P. D., Young, M. A., and Grassian, V. H.: $\mathrm{N}_{2} \mathrm{O}_{5}$ hydrolysis on the components of mineral dust and sea salt aerosol: comparison study in an environmental aerosol reaction chamber, Atmos. Environ., 40, 7401-7408, 2006.

Nie, W., Wang, T., Xue, L. K., Ding, A. J., Wang, X. F., Gao, X. M., Xu, Z., Yu, Y. C., Yuan, C., Zhou, Z. S., Gao, R., Liu, X. H., Wang, Y., Fan, S. J., Poon, S., Zhang, Q. Z., and Wang, W. X.: Asian dust storm observed at a rural mountain site in southern China: chemical evolution and heterogeneous photochemistry, Atmos. Chem. Phys., 12, 11985-11995, doi:10.5194/acp12-11985-2012, 2012.

Parrington, J. R., Zoller, W. H., and Aras, N. K.: Asian dust: seasonal transport to the Hawaiian Islands, Science, 220, 195-197, 1983.

Pathak, R. K., Wang, T., and Wu, W. S.: Nighttime enhancement of $\mathrm{PM}_{2.5}$ nitrate in ammonia-poor atmospheric conditions in Beijing and Shanghai: plausible contributions of heterogeneous hydrolysis of $\mathrm{N}_{2} \mathrm{O}_{5}$ and $\mathrm{HNO}_{3}$ partitioning, Atmos. Environ., 45, 1183-1191, 2011.

Saliba, N. A. and Chamseddine, A.: Uptake of acid pollutants by mineral dust and their effect on aerosol solubility, Atmos. Environ., 46, 256-263, 2012.

Seinfeld, J. H., Carmichael, G. R., Arimoto, R., Conant, W. C., Brechtel, F. J., Bates, T. A., Cahill, T. A., Clarke, A. D., Doherty, S. J., Flatau, P. J., Huebert, B. J., Kim, J., Markowicz, K. M., Quinn, P. K., Russell, L. M., Russell, P. B., Shimizu, A., Shinozuka, Y., Song, C. H., Tang, Y. H., Uno, I., Vogelmann, A. M., Weber, R. J., Woo, J. H., and Zhang, X. Y.: ACEAsia: regional climatic and atmospheric chemical effects of Asian dust and pollution, B. Am. Meteorol. Soc., 85, 367-380, doi:10.1175/BAMS-85-3-367, 2004.

Shen, Z. X., Cao, J. J., Arimoto, R., Zhang, R. J., Jie, D. M., Liu, S. X., and Zhu, C. S.: Chemical composition and source characterization of spring aerosol over Horqin sand land in northeastern China, J. Geophys. Res.-Atmos., 112, D14315, doi:10.1029/2006JD007991, 2007.

Shen, Z., R. Arimoto, J. Cao, R. Zhang, X. Li, N. Du, T. Okuda, S. Nakao, and S. Tanaka: Seasonal Variations and evidence for the effectiveness of pollution controls on water-soluble inorganic species in total suspended particulates and fine particulate patter from Xi' an, China, J. Air Waste Manage. Asso., 58, 1560-1570, 2008.

Singh, H. B., Brune, W. H., Crawford, J. H., Flocke, F., and Jacob, D. J.: Chemistry and transport of pollution over the Gulf of Mexico and the Pacific: spring 2006 INTEX-B campaign 
overview and first results, Atmos. Chem. Phys., 9, 2301-2318, doi:10.5194/acp-9-2301-2009, 2009.

Song, Y.-C., Eom, H.-J., Jung, H.-J., Malek, M. A., Kim, H. K., Geng, H., and Ro, C.-U.: Investigation of aged Asian dust particles by the combined use of quantitative ED-EPMA and ATR-FTIR imaging, Atmos. Chem. Phys., 13, 3463-3480, doi:10.5194/acp-13-3463-2013, 2013.

Sullivan, R. C. and Prather, K. A.: Investigations of the diurnal cycle and mixing state of oxalic acid in individual particles in Asian aerosol outflow, Environ. Sci. Technol., 41, 8062-8069, 2007.

Sullivan, R. C., Guazzotti, S. A., Sodeman, D. A., and Prather, K. A.: Direct observations of the atmospheric processing of Asian mineral dust, Atmos. Chem. Phys., 7, 1213-1236, doi:10.5194/acp-7-1213-2007, 2007.

Sullivan, R. C., Moore, M. J. K., Petters, M. D., Kreidenweis, S. M., Roberts, G. C., and Prather, K. A.: Effect of chemical mixing state on the hygroscopicity and cloud nucleation properties of calcium mineral dust particles, Atmos. Chem. Phys., 9, 33033316, doi:10.5194/acp-9-3303-2009, 2009a.

Sullivan, R. C., Moore, M. J. K., Petters, M. D., Kreidenweis, S. M., Roberts, G. C., and Prather, K. A.: Timescale for hygroscopic conversion of calcite mineral particles through heterogeneous reaction with nitric acid, Phys. Chem. Chem. Phys., 11, 78267837, 2009b.

Sun, Y., Zhuang, G., Huang, K., Li, J., Wang, Q., Wang, Y., Lin, Y., Fu, J. S., Zhang, W., Tang, A., and Zhao, X.: Asian dust over northern China and its impact on the downstream aerosol chemistry in 2004, J. Geophys. Res., 115, D00K09, doi:10.1029/2009jd012757, 2010.

Takahashi, Y., Higashi, M., Furukawa, T., and Mitsunobu, S.: Change of iron species and iron solubility in Asian dust during the long-range transport from western China to Japan, Atmos. Chem. Phys., 11, 11237-11252, doi:10.5194/acp-1111237-2011, 2011

Tobo, Y., Zhang, D., Matsuki, A., and Iwasaka, Y.: Asian dust particles converted into aqueous droplets under remote marine atmospheric conditions, P. Natl. Acad. Sci. USA, 107, 17905-17910, 2010.

Uno, I., Eguchi, K., Yumimoto, K., Takemura, T., Shimizu, A., Uematsu, M., Liu, Z. Y., Wang, Z. F., Hara, Y., and Sugimoto, N.: Asian dust transported one full circuit around the globe, Nat. Geosci., 2, 557-560, 2009.

Usher, C. R., Michel, A. E., and Grassian, V. H.: Reactions on mineral dust, Chem. Rev., 103, 4883-4939, 2003.

van Donkelaar, A., Martin, R. V., Brauer, M., Kahn, R., Levy, R., Verduzco, C., and Villeneuve, P. J.: Global estimates of ambient fine particulate matter concentrations from satellite-based aerosol optical depth: development and application, Environ. Health Persp., 118, 8347-8355, 2010.

Wang, G., Xie, M., Hu, S., Gao, S., Tachibana, E., and Kawamura, K.: Dicarboxylic acids, metals and isotopic compositions of $\mathrm{C}$ and $\mathrm{N}$ in atmospheric aerosols from inland China: implications for dust and coal burning emission and secondary aerosol formation, Atmos. Chem. Phys., 10, 6087-6096, doi:10.5194/acp-10-6087-2010, 2010.
Wang, G., Li, J., Cheng, C., Hu, S., Xie, M., Gao, S., Zhou, B., Dai, W., Cao, J., and An, Z.: Observation of atmospheric aerosols at Mt. Hua and Mt. Tai in central and east China during spring 2009 - Part 1: EC, OC and inorganic ions, Atmos. Chem. Phys., 11, 4221-4235, doi:10.5194/acp-11-4221-2011, 2011.

Wang, G. H., Li, J. J., Cheng, C. L., Zhou, B. H., Xie, M. J., Hu, S. Y., Meng, J. J., Sun, T., Ren, Y. Q., Cao, J. J., Liu, S. X., Zhang, T., and Zhao, Z. Z.: Observation of atmospheric aerosols at Mt. Hua and Mt. Tai in central and east China during spring 2009 - Part 2: Impact of dust storm on organic aerosol composition and size distribution, Atmos. Chem. Phys., 12, 4065-4080, doi:10.5194/acp-12-4065-2012, 2012.

Wang, G. H., Zhou, B. H., Cheng, C. L., Cao, J. J., Li, J. J., Meng, J. J., Tao, J., Zhang, R. J., and Fu, P. Q.: Impact of Gobi desert dust on aerosol chemistry of Xi'an, inland China during spring 2009: differences in composition and size distribution between the urban ground surface and the mountain atmosphere, Atmos. Chem. Phys., 13, 819-835, doi:10.5194/acp-13819-2013, 2013.

Wang, S. W., Zhang, Q., Streets, D. G., He, K. B., Martin, R. V., Lamsal, L. N., Chen, D., Lei, Y., and Lu, Z.: Growth in $\mathrm{NO}_{\mathrm{x}}$ emissions from power plants in China: bottom-up estimates and satellite observations, Atmos. Chem. Phys., 12, 4429-4447, doi:10.5194/acp-12-4429-2012, 2012.

Wang, Y., Zhang, Q. Q., He, K., Zhang, Q., and Chai, L.: Sulfatenitrate-ammonium aerosols over China: response to 2000-2015 emission changes of sulfur dioxide, nitrogen oxides, and ammonia, Atmos. Chem. Phys., 13, 2635-2652, doi:10.5194/acp-132635-2013, 2013.

Wang, Y. H., Hu, B., Ji, D. S., Liu, Z. R., Tang, G. Q., Xin, J. Y., Zhang, H. X., Song, T., Wang, L. L., Gao, W. K., Wang, X. K., and Wang, Y. S.: Ozone weekend effects in the Beijing-TianjinHebei metropolitan area, China, Atmos. Chem. Phys., 14, 2419 2429, doi:10.5194/acp-14-2419-2014, 2014.

Wu, F., Zhang, D., Cao, J., Xu, H., and An, Z.: Soil-derived sulfate in atmospheric dust particles at Taklimakan desert, Geophys. Res. Lett., 39, L24803, doi:10.1029/2012GL054406, 2012.

Zamora, L. M., Prospero, J. M., and Hansell, D. A.: Organic nitrogen in aerosols and precipitation at Barbados and Miami: implications regarding sources, transport and deposition to the western subtropical North Atlantic, J. Geophys. Res., 116, D20309, doi:10.1029/2011JD015660, 2011.

Zamora, L. M., Prospero, J. M., Hansell, D. A., and Trapp, J. M.: Atmospheric P deposition to the subtropical North Atlantic: sources, properties, and relationship to $\mathrm{N}$ deposition, J. Geophys. Res.-Atmos., 118, 1546-1562, doi:10.1002/jgrd.50187, 2013.

Zhang, Q., Streets, D. G., Carmichael, G. R., He, K. B., Huo, H., Kannari, A., Klimont, Z., Park, I. S., Reddy, S., Fu, J. S., Chen, D., Duan, L., Lei, Y., Wang, L. T., and Yao, Z. L.: Asian emissions in 2006 for the NASA INTEX-B mission, Atmos. Chem. Phys., 9, 5131-5153, doi:10.5194/acp-9-5131-2009, 2009.

Zheng, X.: Salt lakes on the Inner Mongolian plateau of China, Chinese Geographic Science, 1, 83-94, 1991. 